\title{
Seaweed aquaculture: a preliminary assessment of biosecurity measures for controlling the ice-ice syndrome and pest outbreaks of a Kappaphycus farm
}

\author{
Cicilia S. B. Kambey ${ }^{1}$ (D) Iona Campbell ${ }^{2}$ Elizabeth J. Cottier-Cook ${ }^{2} \cdot$ Adibi R. M. Nor $^{3} \cdot$ Azhar Kassim $^{4}$. \\ Ahemad Sade ${ }^{4}$. Phaik E. Lim ${ }^{1}$
}

Received: 23 February 2021 / Revised and accepted: 6 June 2021 / Published online: 2 August 2021

(c) The Author(s) 2021

\begin{abstract}
The application of biosecurity in seaweed aquaculture plays an important role in reducing the impact of disease and pest outbreaks. The continuous occurrence of seaweed pests including the macroalgal epiphytes, epi-endophytic filamentous algae and biofilms on Kappaphycus farms may also potentially induce further incidences of the ice-ice syndrome. In this study, on-farm biosecurity management measures were tested on the commercially grown seaweeds Kappaphycus malesianus and Kappaphycus alvarezii during peak ice-ice season at Gallam-Gallam Village, Sabah, Malaysia. The investigation was focused on preventative control measures including the early detection of the ice-ice syndrome and pests through propagule health checks, regular cleaning of the crop thallus and associated long-line ropes and monitoring of the environment. Farm procedures and practices were also assessed in terms of their biosecurity 'risk' using the hazard analysis and critical control point (HCCAP) approach. Observations were replicated in two different farm management systems; one system adopted routine biosecurity measures and the other had no biosecurity measures. The results showed that the ice-ice syndrome and pest outbreak was significantly decreased by $60-75 \%$ for $K$. malesianus and $29-71 \%$ for K. alvarezii at the farm which adopted the routine biosecurity measures compared with the no biosecurity treatment. The biosecurity measures also significantly improved growth rate and seaweed quality. The infection levels of the epi-endophyte Melanothamnus sp. contributed to the ice-ice syndrome in K. malesianus, whilst the epiphyte coverage was correlated to the ice-ice incidence in $K$. alvarezii. This study provides the first evidence of biosecurity management measures significantly decreasing the incidence of the ice-ice syndrome and pests on a commercial seaweed farm.
\end{abstract}

Keywords Biosecurity $\cdot$ Farm practices $\cdot$ Ice-ice syndrome $\cdot$ Kappaphycus farm $\cdot$ Rhodophyta $\cdot$ Seaweed aquaculture

Phaik E. Lim

phaikeem@um.edu.my

1 Institute of Ocean and Earth Sciences, University of Malaya, 50603 Kuala Lumpur, Malaysia

2 Scottish Association for Marine Science, Oban, Argyll PA37 1QA, UK

3 Institute for Advanced Studies, University of Malaya, 50603 Kuala Lumpur, Malaysia

4 Department of Fisheries Sabah, 88624 Kota Kinabalu, Sabah, Malaysia

\section{Introduction}

Seaweed is highly nutritious and has been consumed by humans for centuries. In 2018, the total production of world seaweed aquaculture reached 32 million tonnes fresh weight (FW), increasing by $200 \%$ within eight years (FAO 2020). The red seaweed Kappaphycus/Eucheuma has been reported to be the most rapidly expanding sector of the seaweed market and recently contributed to $34 \%$ of the world's seaweed production (FAO 2020). South-East Asia is a major global producer of Kappaphycus/Eucheuma and the industry has supported national economic growth and significantly improved the livelihood of millions of farmers (Valderrama et al. 2015; Cottier-Cook et al. 2016; FAO 2020).

Changes in the aquatic environment, however, as a consequence of global climate change have had led to significant 
impacts on the biological and chemical responses of seaweeds, particularly relating to increased seawater temperature and eutrophication (Chung et al. 2017; Duarte et al. 2017; Roleda and Hurd 2019; Campbell et al. 2019; Kumar et al. 2020). The occurrence of 'ice-ice' syndrome in eucheumatoid farms, defined as the whitening/discolouration of old thallus that causes the massive fragmentation and degradation of seaweed quality, has become a major problem for the seaweed industry (Valderrama et al. 2015; Hurtado et al. 2019; Largo et al. 2020). The causative agents and the pathways of the ice-ice syndrome have been identified and reported (Ward et al. 2020). Elevation of seawater temperature, high variability in salinity and the availability of seaweed pests have been shown to be key factors in increasing the susceptibility of Kappaphycus/Eucheuma to the infectious microbial pathogens, which can cause an iceice syndrome (Vairappan et al. 2010; Pang et al. 2015; Largo et al. 2020; Kopprio et al. 2021). Epiphytic macroalgae are also considered to be a major pest by eucheumatoid seaweed farmers, as they are associated with a high mortality of the whole or partial thallus, reduced growth rates and decreased reproduction (Vairappan 2006; Vairappan et al. 2010; Wahl et al. 2012; Ingle et al. 2018). In addition, epi-endophytic filamentous algae, which are now almost ubiquitous on Kappaphycus/Eucheuma farms throughout South-East Asia, can devastate the health condition and quality of the crop (Mendoza et al. 2002; Hurtado et al. 2019; Ali et al. 2020). More recent studies have also found that the holobiont effect on seaweed bacteria, which are typically found on the seaweed surface, can affect health performance and resilience (Wahl et al. 2012; Ward et al. 2020). These factors have subsequently impacted the sustainability of the Kappaphycus/ Eucheuma value chain, which supports the viability of this industry (Nor et al. 2020). As a consequence, the production of eucheumatoid seaweeds declined by $10 \%$ in Indonesia and Malaysia in 2018 (FAO 2020). Minimal biosecurity guidance and regulations in the majority of countries producing seaweeds in South-East Asia and globally have also exacerbated the problem of the ice-ice syndrome and pest outbreaks in the seaweed eucheumatoid industry (Campbell et al. 2020; Mateo et al. 2020; Rusekwa et al. 2020; Kambey et al. 2020a).

In Malaysia, eucheumatoid seaweed production has significantly declined from 331 to 173 thousand tonnes fresh weight (FW) from 2012 to 2018, respectively (DOFM 2020; FAO 2020). This decline has been primarily caused by persistent outbreaks of ice-ice syndrome during the hot-dry monsoon season, which has led to a short supply of healthy propagules for restocking purposes (Lim et al. 2013; Vairappan et al. 2014; Eranza et al. 2017; Ali et al. 2020). Since 2005, cultivation of Eucheuma spp. was even halted due to a severe ice-ice outbreak in Kudat, Sabah-a once, highly productive region in Malaysia (Vairappan 2006;
Vairappan et al. 2008). The outbreak has continued over the last few years at Omadal Island and the nearby Semporna region, where the majority of the seaweed is cultivated (Eranza et al. 2017). High epiphyte and epi-endophyte infestations on seaweed thallus and associated long lines, such as Laurencia sp. and Neoshiponia sp. in productive areas at Selakan Island and Blambangan Island, were also linked to the occurrence of the ice-ice syndrome (Vairappan et al. 2008, 2010). The local and national economic loss due to the syndrome has been reported in previous studies (Sade et al. 2006; Kaur and Ang 2009; Vairappan et al. 2010; Eranza et al. 2017; Nor et al. 2020). In addition, a lack of farm management practices related to reducing the risk of the syndrome and pest outbreaks in the productive areas in Malaysia may be having a detrimental effect on the sustainability of the seaweed industry (Vairappan et al. 2008, 2010; Eranza et al. 2017). Grazing pressure by turtles in areas not subjected to the ice-ice incidence and pest outbreaks has also severely compromised the industry in Malaysia (Ali et al. 2020; Nor et al. 2020).

Biosecurity is a proven means of minimising the introduction and subsequent spread of disease and pests in many aquaculture industries and it has driven research into farm management measures and practices, which can contribute to product sustainability (Rodgers et al. 2015; BondadReantaso et al. 2018; Scarfe and Palić 2020). The adoption of the biosecurity concept, including application and risk management, by the seaweed industry has been identified as far behind other aquaculture industries (Campbell et al. 2020). In fish aquaculture, using the biosecurity approach to sustain the production system by introducing effective management practices has significantly reduced disease outbreaks (Mohan et al. 2008; Bondad-Reantaso et al. 2018; Subasinghe et al. 2019). In eucheumatoid farming, however, effective management practices for reducing the risk of the ice-ice syndrome and pest outbreaks are lacking. Very few quarantine procedures exist, the farming guidelines contain minimal biosecurity-related guidance, no surveillance methods for controlling outbreaks on the farm exist and there are no standardised methods of ensuring the health quality of the harvested Kappaphycus/Eucheuma crop (Sulu et al. 2004; Azanza and Ask 2017; Rusekwa et al. 2020; Mateo et al. 2020). Currently, the existing measures include the use of a commercial fertiliser and biostimulants to improve seaweed health (DOFM 2012; Yong et al. 2014; Loureiro et al. 2017; Ali et al. 2020), but these measures, however, do not offer any control or mitigation measures for the ice-ice syndrome or pest occurrence and there is a general lack of biosecurity concern regarding wider environmental sustainability. In Malaysia, the Department of Fisheries Malaysia has introduced guidelines for cultivating Kappaphycus/Euchema (DOFM 2012; Department of Standards Malaysia 2012), which also includes some general biosecurity-related 
measures. This initiative, however, has not been widely disseminated at the industry level, due to poor engagement and lack of awareness of the programme amongst stakeholders (Nor et al. 2017, 2020).

The implementation of scientifically robust, seaweedspecific biosecurity measures, therefore, is crucial for the industry to thrive. The identification of high-risk pathways and the introduction of effective management procedures to control the impact of the ice-ice syndrome and pest outbreaks are imperative to enable the industry to tackle this significant problem (Ingle et al. 2018; Campbell et al. 2019). The biosecurity management practices though should be simple, science-based, cost-effective, appropriate to their context (Mohan et al. 2008) and positively contribute to food security, market acceptability and provide a healthier environment (Cottier-Cook et al. 2016; Bondad-Reantaso et al. 2018; Hurtado et al. 2019; Campbell et al. 2019, 2020). Evidence of how biosecurity measures impact crop outcomes in terms of production and quality are, therefore, needed to support evidencebased policy and industry decisions.

To provide this evidence, an assessment of the application of basic biosecurity measures on a commercial Kappaphycus spp. farm was conducted. In addition, biosecurity-related risks were identified and documented to inform future biosecurity plans. The aims of the study included (1) assessing the effectiveness of biosecurity measures for reducing ice-ice syndrome and farm risk in two different treatment systems by comparing the ice-ice incidence and the pest coverages, (2) comparing crop quality between a farm system adopting basic biosecurity measures with a farm with no biosecurity measures, (3) assessing the environmental parameters, which may influence the occurrence of the ice-ice syndrome and/or pests outbreaks and 4) conducting a farm risk identification for biosecurity-related hazards.

\section{Materials and methods}

\section{Study site}

A field study was conducted at the seaweed aquaculture site in Gallam-Gallam Village, Bum-Bum Island, Semporna, Sabah $\left(\mathrm{N} 04^{\circ} 29.44 .0\right.$, E $\left.118^{\circ} 39.30 .8\right)$ from 18 June to 28 July 2019 (Fig. 1). The observation was carried out during a period known for high ice-ice incidence and pest outbreaks in the seaweed farm in the Semporna area (May-August; DOFM 2020). No seaweed was cultivated commercially in the area during this period. The cultivation area is situated $500 \mathrm{~m}$ from the coastline and surrounded by hard coral, with an average water depth of 3-4 m. The water parameters showed initial temperature, salinity, turbidity and water currents ranging from $29.9-30.0{ }^{\circ} \mathrm{C}, 31-33 \%$ o, 3-4 m and $<0.1$ to $0.18 \mathrm{~m} \mathrm{~s}^{-1}$, respectively.

\section{Farm preparation and experimental design}

The experimental farm was set up for the culture of two commercial species of Kappaphycus alvarezii and Kappaphycus malesianus. For both species, propagules were collected vegetatively from existing farms in Karindingan Island, also in the Semporna region, where widespread

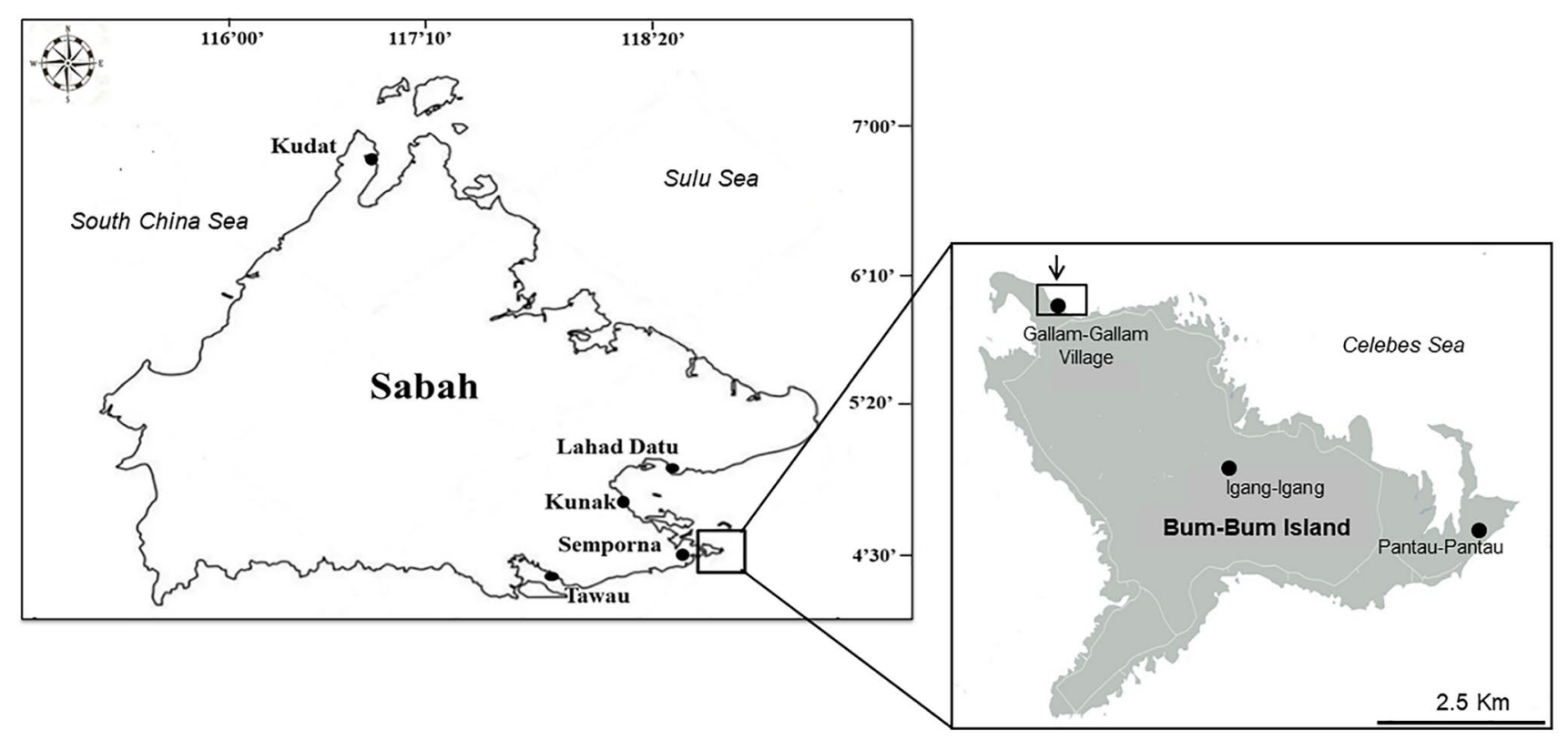

Fig. 1 Map of Sabah State and the location of farm site in Gallam-Gallam Village 
disease and pest outbreaks are less and the crop is considered good quality (DOFM 2020). Approximately $15 \mathrm{~kg}$ of propagules was transported in a cool box to the GallamGallam Village, using boat transportation in less than an hour. Pre-deployment, a basic health check was conducted at the working place (platform), where each of the individual propagule was visually checked for signs of bleaching or discolouration, wounds, epiphyte/epi-endophytes, biofilm waste, general biofouling or any other unwanted associated material. Propagules with any signs of ill health and/or pests including those covered by epiphytes, epi-endophytes, biofilm, or biofouling attached were discarded to landfill and not included in the experiment. All the experimental farm equipment was purchased as new, including the main culture ropes, line ropes, propagule ties ropes and plastic flotation buoys. The use of old rope was avoided as it was considered a high-risk mode of transmission of microbial pathogen and pests to the new crop.

Two identical farms were established: one farm with the implementation of biosecurity measures and the other farm with normal cultivation processes (i.e., without the application of any measures) (Table 1). The biosecurity treatment farm (BTF) and the non-biosecurity treatment farm (NBTF) were evaluated over 40-day culture periods (normal growing period 30-45 days). Each treatment farm was approximately
$500 \mathrm{~m}$ apart to ensure there was no interference between the two farms and the current flow direction was also considered when installing the farms to minimise the transfer of material or propagules from one farm to another. At each farm, five horizontal ropes for the seaweed $K$. alvarezii and five ropes for $K$. malesianus were deployed separately and 50 individual propagules (bundle) of each species were deployed at both treatment farms (Fig. 2). Each bundle consisted of $50 \mathrm{~g} \mathrm{FW}$ and the initial weight was chosen to avoid overgrowth during observation. The common long-line cultivation technique was used in this experiment.

\section{Environmental parameters measurement}

Environmental parameters including temperature, salinity and $\mathrm{pH}$ were measured in situ using a YSI Pro Plus multiparameter probe (Arachem Inc.). The water current was measured using Portable Current Meter (Mirong LJ20-A, Nanjing, China). The parameters were measured at the beginning of the cultivation period and then regularly every 3 to 4 days depending on weather conditions at $09.00 \mathrm{AM}$. Measurements of inorganic ammonium $\left(\mathrm{NH}_{4}{ }^{+}\right)$and nitrate $\left(\mathrm{NO}_{3}{ }^{-}\right)$were taken at the same time as the environmental parameters. The nutrient samples were taken between the horizontal ropes and close to a seaweed line at both farm

Table 1 Biosecurity measures applied in two treatment farms

\begin{tabular}{|c|c|c|}
\hline Biosecurity measure & BTF & NBTF \\
\hline 1. Propagules treatment & $\begin{array}{l}\text { Visually health checked for thallus bleached, } \\
\text { wounds, epiphytes/epi-endophytes, biofilm, fouling } \\
\text { organisms, waste material attached at the preparation, } \\
\text { grow-out and harvest } \\
\text { Only used the propagules with healthy sign, many } \\
\text { shoot tips and visually cleaned from pests attached } \\
\text { Source of propagules known }\end{array}$ & $\begin{array}{l}\text { Visually health checked for the propagules was ran- } \\
\text { domly carried out in the preparation process only. } \\
\text { Initial propagule used as BTF } \\
\text { Source of propagules known }\end{array}$ \\
\hline 2. Farm equipment treatment & $\begin{array}{l}\text { Newly purchased ropes (anchor ropes, planting ropes } \\
\text { and tying ropes) } \\
\text { The boat was cleaned and sun-dried before use. }\end{array}$ & O As BTF \\
\hline 3. Cleaning treatment & $\begin{array}{l}\text { Epiphytes/epi-endophytes, biofilm, fouling and all } \\
\text { waste attached were carefully removed manually } \\
\text { from the crop and the ropes (using tissue paper or } \\
\text { soft fabrics). } \\
\text { B Bleached/discoloured thallus removed from the farm } \\
\text { by cutting the bleached thallus apart }\end{array}$ & $\begin{array}{l}\text { O Seaweed crops and ropes were left uncleaned. } \\
\text { Bleached/discoloured thallus was fragmented natu- } \\
\text { rally without maintenance. }\end{array}$ \\
\hline 4. Farm waste treatment & $\begin{array}{l}\text { All bleached/discoloured thallus, epiphytes/epi- } \\
\text { endophytes, biofilm and all waste materials were } \\
\text { gathered and disposed landfill, and avoided to throw } \\
\text { within farm area. }\end{array}$ & $\begin{array}{l}\text { O No measure in maintaining the farm wastes included } \\
\text { the bleached/discoloured thallus and the pests } \\
\text { attached }\end{array}$ \\
\hline 5. Environment monitor & $\begin{array}{l}\text { Physical environmental parameters were measured } \\
\text { at the beginning of the experiment and regularly } \\
\text { throughout the grow-out phase within 3-4 days. }\end{array}$ & O As BTF \\
\hline 6. Monitoring and evaluation & $\begin{array}{l}\text { O Every } 2 \text { days for cleaning and removing pests, } \\
\text { bleached, and checking the health status of crops } \\
\text { Every } 10 \text { days for measuring the growth, pests cov- } \\
\text { erage and ice-ice incidence }\end{array}$ & $\begin{array}{l}\text { Measuring the growth, pests coverage and ice-ice } \\
\text { incidence as BTF } \\
\text { No cleaning, removing and checking health of crops }\end{array}$ \\
\hline
\end{tabular}


Fig. 2 The experimental design of two treatment farms
Biosecurity treatment farm (BTF)

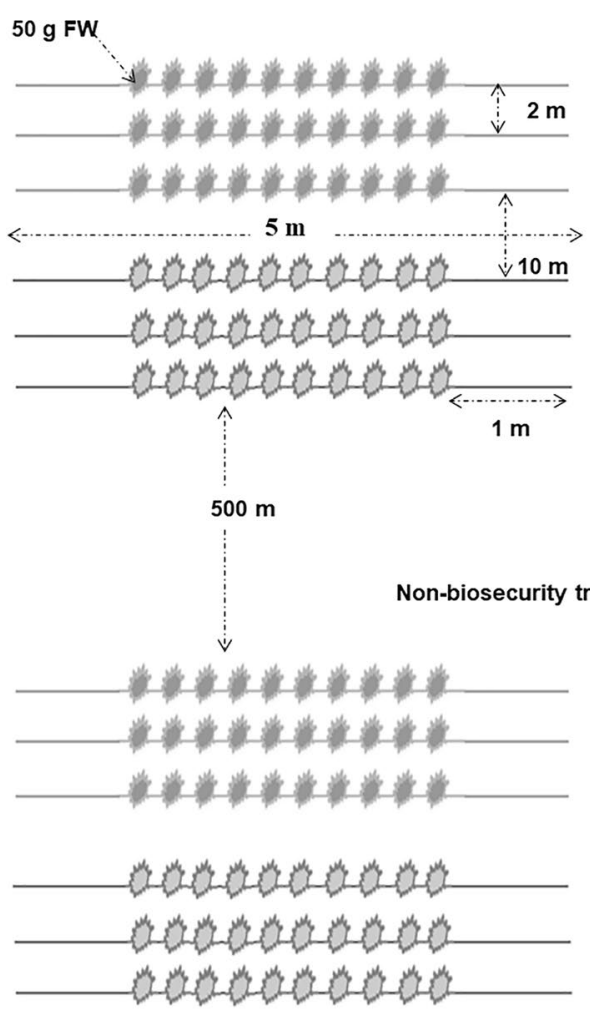

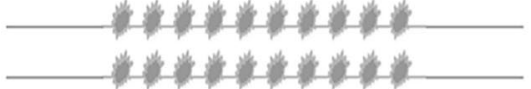

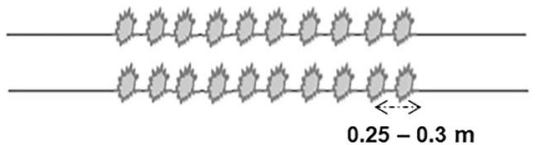

$0.25-0.3 \mathrm{~m}$

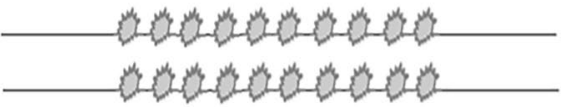

Current flow

sites using a Niskin bottle, from a depth of approximately $1 \mathrm{~m}$. The water samples were immediately filtered through $0.45-\mu \mathrm{m}$ pore size placed in a $50-\mathrm{mL}$ container tube and kept frozen for further analysis. The nutrient concentrations were determined in the laboratory; $\mathrm{NH}_{4}{ }^{+}$and $\mathrm{NO}_{3}{ }^{-}$were analysed using the APHA $4500 \mathrm{NH}_{3} \mathrm{~B}$-based method and $\mathrm{CH} 17-16$ based method, respectively. All environmental data were obtained through three replicates and are presented as their average values.

\section{Pest coverage}

The measurement of the seaweed Kappaphycus pest coverage included macroalgal epiphytes, epi-endophytic filamentous algae and biofilms in each seaweed bundle. Coverage was calculated based on the percentage area covered by the individual pest over the entire bundle. A hundred percent (100\%) area covered was recorded if the epiphytes, epi-endophytes and biofilm covered the entire seaweed bundle: $50 \%$ cover rate if the pest covered half the bundle; $25 \%$ cover rate if the pest covered a quarter of the bundle and so on. The average of epiphytes, epi-endophytes and biofilm coverage in each farm and each Kappaphycus species, was calculated based on the total percentage of the epiphytes, epi-endophytes and biofilm-cover in each bundle, divided by the total number of available bundles in each farm. The measurement of the pest coverage was obtained every 10 days at both farms. Detailed photographs of the epiphytes and epi-endophytes were taken for species identification using a digital camera, whilst biofilm samples were not included in the species identification.

\section{Ice-ice incidence}

All seaweed bundles were observed closely for the occurrence of the ice-ice syndrome, in particular the secondary or primary branches of the thallus, in which bleaching typically occurs. Any tip, bleached or desiccated as a result of air exposure, was discounted as an ice-ice syndrome. Calculation of the incidence of ice-ice in each farm was measured from the total number of infected bundles divided by available bundles in the farm. The higher the proportion of infected seaweed bundles, the higher the ice-ice syndrome risk on the farm.

\section{Seaweed quality measurement}

Twenty bundles of each species from each farm were randomly measured for growth rate. The growth rate was calculated by weighing individual bundles every 10 days 
(together with the ice-ice incidence and pest measurements). The growth measurement was obtained by calculating the specific growth rate (SGR) using the following equation:

$\operatorname{SGR}\left(\%\right.$ day $\left.^{-1}\right)=\frac{\left\lfloor\operatorname{In}\left(\left(\mathrm{W}_{\mathrm{t}}\right)-\operatorname{In}\left(\mathrm{W}_{0}\right)\right)\right\rfloor}{\mathrm{t}} \times 100$

where SGR is specific growth rate $\left(\%\right.$ day $\left.^{-1}\right), \mathrm{W}_{\mathrm{t}}$ and $\mathrm{W}_{0}$ are the final and initial weights ( $\mathrm{g} \mathrm{FW}$ ), respectively and $t$ is the time of the observation period (day).

To measure seaweed quality, the bleached infected bundles $(n=5)$ and healthy bundles $(n=20)$ were analysed for semi-refined carrageenan yield and gel strength following the methods previously described by Yong et al. (2014). The carrageenan yield (\%) was calculated from the semi-refined carrageenan weight $(\mathrm{CW})$ divided by the initial seaweed dried weight (SW), whilst the gel strength $\left(\mathrm{g} \mathrm{m}^{-2}\right)$ was quantified using a rheometer. The seaweed quality measurement of each bundle was analysed in triplicate.

\section{Identifying farm biosecurity risk}

The biosecurity-related risks for each farm were identified based on farm processes from propagule preparation, growout and harvest over a 40-day observation. Potential risks and mitigation measures in each farm phase were identified based on current farm practices, existing literature on-farm regulations in Malaysia and experience-based studies. The literature reviewed provided a theoretical baseline for limiting the risk level.

\section{Data analysis}

Data of the environmental parameters, pest coverage and ice-ice incidence, and the seaweed growth rate in both farms were tested for normality and homogeneity using the Kolmogorov-Smirnov and Levene's tests. For data analysis, the environmental parameter data were normally distributed and categorised into four groups following the four periods of observation. Significant differences in each of the environmental parameters between farm and farm period were tested using a two-way ANOVA, followed by post hoc Tukey's HSD to make pairwise comparisons of the treatment means amongst farm period. To observe the trend amongst the environmental parameters in each farm, a simple regression analysis was conducted. Percentage pest coverage and the ice-ice incidences on both farms did not show any normality; therefore, these data were run using nonparametric Kruskal-Wallis to test for significant differences between the two treatment farms. Spearman rank correlation was used to determine which pests (epiphytes, epi-endophytes and biofilm) were closely correlated with the incidence of ice-ice syndrome in each species and farm. The SGR of seaweed between farms and farm period was calculated using a twoway ANOVA, and the Pairwise t-test was used to observe the value of carrageenan yield and gel strength between farms. Calculation of the averages (mean) was given with the standard error (SE) and with the significance difference set at 0.05 . The statistical analysis was performed using SPSS Version 23.0 (IBM, USA).

\section{Results}

\section{Environmental parameters}

During the cultivation period, the water temperature was shown to have slightly increased from pre-deployment measurement in the range of 29.2 to $30.7^{\circ} \mathrm{C}$, with an average of $29.96 \pm 0.1$ at the BTF and $29.88 \pm 0.1$ at the NBTF. No significant difference in temperature was detected between the two treatment farms $(p=0.37 ; \mathrm{F}=0.80)$, among farm period $(p=0.82 ; \mathrm{F}=0.31)$ and the interaction between farms and farm period $(p=0.79 ; \mathrm{F}=0.35)$ (Fig. 3, Table 2). The water salinity varied from 31.86 to $33.77 \%$ at both farms with mean $33.17 \pm 0.1 \%$ and $33.13 \pm 0.1 \%$, at the BTF and NBTF, respectively. Heavy rains in the initial cultivation period decreased the salinity to $31.8 \%$ and it continued to increase thereafter (Fig. 3). No significant difference in salinity was found between farms and the interaction between farms and farm periods $(p=1.00)$ (Table 2).

The seawater $\mathrm{pH}$ value ranged from 7.71 to 8.09 and was significantly greater at the BTF with an average of 8.01 \pm 0.01 compared with the NBTF with an average of 7.97 $\pm 0.01(p<0.05 ; \mathrm{F}=9.24)$. The seawater $\mathrm{pH}$ showed an increasing trend over the farming period at the BTF compared with the NBTF $(p<0.05 ; \mathrm{F}=9.24)$ (Fig. 3). However, the interaction between farms and farm period showed no significant difference in the $\mathrm{pH}$ values $(p=0.67 ; \mathrm{F}=0.51)$. Similarly, water current showed a consistent range of speed from 0.08 to $0.17 \mathrm{~m} \mathrm{~s}^{-1}$ at both farms with an average 0.08 $\pm 0.01 \mathrm{~m} \mathrm{~s}^{-1}$ at the BTF and $0.09 \pm 0.01 \mathrm{~m} \mathrm{~s}^{-1}$ at the NBTF $(p=0.82 ; \mathrm{F}=0.51)$. The water current speed was not statistically differed in the interaction between farms and farm period ( $p=0.73 ; \mathrm{F}=0.44)$ (Fig. 3, Table 2).

Inorganic nutrients $\mathrm{NH}_{4}^{+}$at the BTF and NBTF, ranged from 0.09 to $0.51 \mathrm{mg} \mathrm{L}^{-1}(0.19 \pm 0.02)$ and from 0.06 to $0.5 \mathrm{mg} \mathrm{L}^{-1}(0.22 \pm 0.02)$, respectively. The concentrations of the nutrient significantly fluctuated over time $(p<0.05 ; \mathrm{F}=$ 6.53), but there was no significant difference in concentrations between the two farms $(p=0.36 ; \mathrm{F}=0.84)$ and the interaction between farms and farm period $(p=0.48 ; \mathrm{F}=0.82)$ (Table 2). The concentrations of inorganic $\mathrm{NO}_{3}{ }^{-}$were lower at the NBTF with ranges from $<0.01$ to $0.04 \mathrm{mg} \mathrm{L}^{-1}(0.02$ $\left.\pm 0.01 \mathrm{mg} \mathrm{L}^{-1}\right)$, compared with the BTF ranged from $<0.01$ to $0.15 \mathrm{mg} \mathrm{L}^{-1}\left(0.04 \pm 0.01 \mathrm{mg} \mathrm{L}^{-1}\right)(p<0.05 ; \mathrm{F}=26.26)$ 
Fig. 3 Temporal variability of seawater temperature, salinity, $\mathrm{pH}$ and water current at the $\mathrm{BTF}$ (black colour) and the NBTF (grey colour) during the cultivation period from 18 June to 28 July 2019
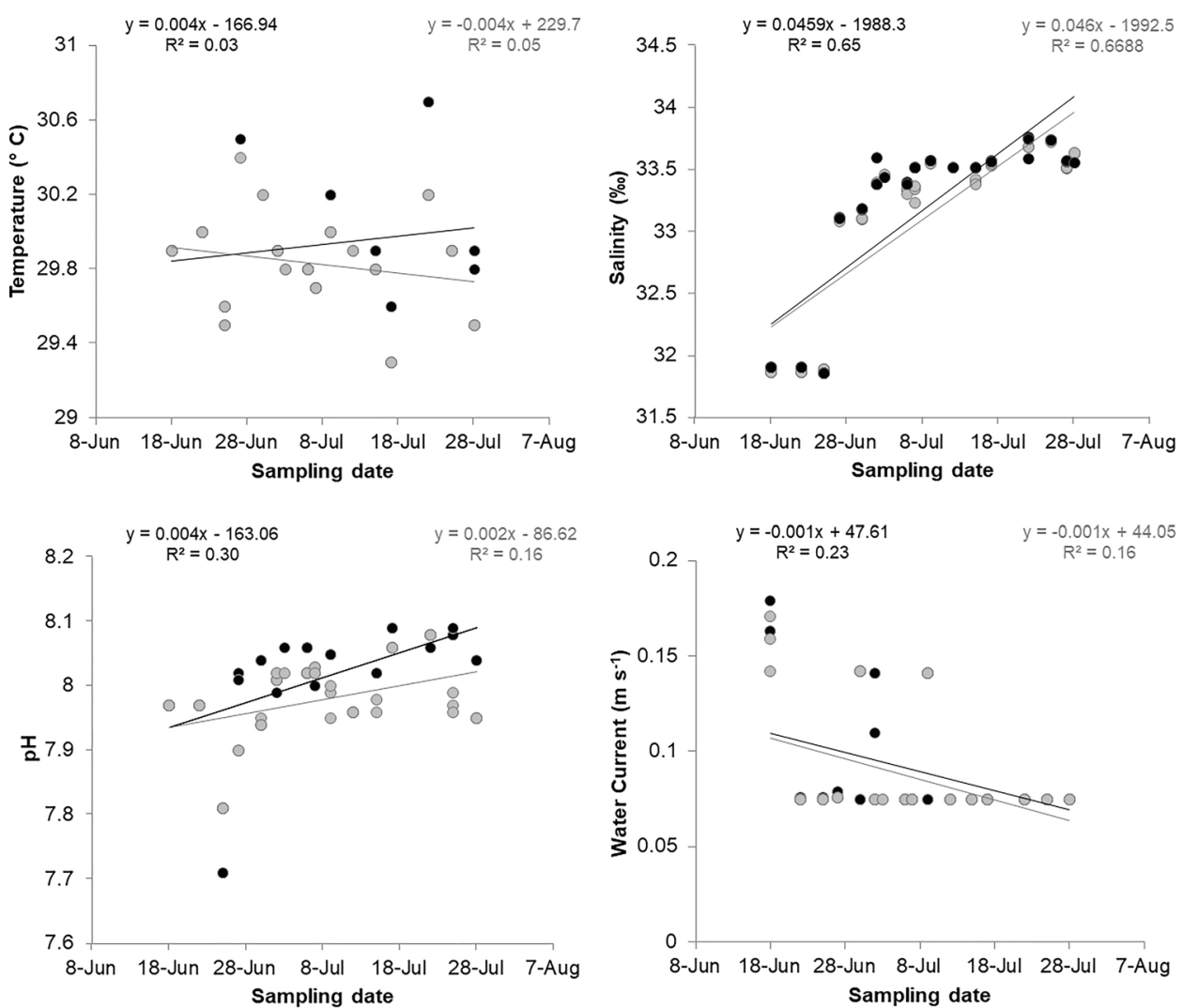

(Fig. 4). The results indicated a significant difference in the interaction between farms and farm period with value $p<$ $0.05 ; \mathrm{F}=13.18$ (Table 2).

\section{Ice-ice incidence}

The incidence of ice-ice syndrome in K. malesianus and $K$. alvarezii between farms was significantly different (Kruskal-Wallis $p<0.05$ ) with a lower rate at the BTF (Fig. 5a, b) compared to the NBTF (Fig. 5c, d). The iceice incidence at the BTF in each period showed an average rate of $5.50 \pm 0.8 \%$ in K. malesianus and $4.50 \pm 1.8 \%$ in $K$. alvarezii, whilst at the NBTF the incidence was found higher to average $25.0 \pm 2.3 \%$ and $11.5 \pm 1.3 \%$, respectively. The ice-ice syndrome was initially recorded after 20 days at the BTF with an average rate $<10 \%$ in both species. However, at the NBTF, the ice-ice incidence was recorded within 10 days, with an average rate of $26.0 \pm 0.8 \%$ and $10.0 \pm$ $0.2 \%$ in $K$. malesianus and $K$. alvarezii, respectively, and the rates were increased periodically. By the final day (40 days), healthy bundles of $K$. malesianus and $K$. alvarezii were retained $92 \%$ and $96 \%$ at the BTF, respectively, whilst at the NBTF the healthy bundles were only $68 \%$ and $86 \%$, respectively. The bleached thallus defined as either ice-ice syndrome or non-ice-ice syndrome is shown in Fig. 6a-d.

\section{Pest coverages}

The rate of epiphyte coverage in $K$. malesianus and $K$. alvarezii at both farms showed a significant difference (Kruskal-Wallis $p<0.05$ ). The average rate of epiphyte coverage on the seaweed thallus at the BTF was significantly lower, at a rate of $3.52 \pm 0.3 \%$ in K. malesianus and $4.32 \pm 1.2 \%$ in K. alvarezii (Fig. 5a, b) compared with the average rate at the NBTF of $31.67 \pm 0.01 \%$ and $16.39 \pm$ $0.01 \%$, respectively (Fig. 5 c, d). A significant increase in epiphyte coverage was observed, along with increasing epi-endophytes, in both species and farms (Tables 3 and 4). However, the epiphyte coverage had a low correlation with the ice-ice incidence in $K$. alvarezii at the BTF and NBTF $(\mathrm{r}=0.18 ; p=0.01$ and $\mathrm{r}=0.14 ; p=0.04$, respectively $)$ and no correlation with the ice-ice incidence in $K$. malesianus (Tables 3 and 4).

During the observation period, the epi-endophyte coverage in $K$. malesianus was higher at the NBTF with an average of $17.34 \pm 7.5 \%$ compared with the BTF with an average of $14.98 \pm 3.0 \%$ (Fig. 5a, c). High epiendophyte coverage in $K$. alvarezii at the NBTF was also detected with an average of $5.81 \pm 0.9 \%$ compared with $4.52 \pm 1.1 \%$ at the BTF (Fig. 5 b, d). The coverage of epiendophytes on the two Kappaphycus species was shown to be significantly different between the BTF and NBTF 
Table 2 Two-way ANOVA of the environmental parameters in both farms and farm periods

\begin{tabular}{|c|c|c|c|c|c|}
\hline Variable & $\begin{array}{l}\text { Source of vari- } \\
\text { ation }\end{array}$ & $\mathrm{df}$ & Mean square & F value & $p$ value \\
\hline \multirow[t]{3}{*}{ Temperature } & Farm & 1 & 0.08 & 0.80 & 0.37 \\
\hline & Farm period & 3 & 0.03 & 0.31 & 0.82 \\
\hline & $\begin{array}{l}\text { Farm } \times \text { farm } \\
\text { period }\end{array}$ & 3 & 0.04 & 0.35 & 0.79 \\
\hline \multirow[t]{3}{*}{ Salinity } & Farm & 1 & 0.00 & 0.00 & 1.00 \\
\hline & Farm period & 3 & 10.55 & 121.57 & $<0.001$ \\
\hline & $\begin{array}{l}\text { Farm } \times \text { farm } \\
\text { period }\end{array}$ & 3 & 0.0 & 0.0 & 1.00 \\
\hline \multirow[t]{3}{*}{ Water current } & Farm & 1 & 0.03 & 0.51 & 0.82 \\
\hline & Farm period & 3 & 0.0 & 3.24 & $0.03^{*}$ \\
\hline & $\begin{array}{l}\text { Farm } \times \text { farm } \\
\text { period }\end{array}$ & 3 & 0.0 & 0.44 & 0.73 \\
\hline \multirow[t]{3}{*}{$\mathrm{pH}$} & Farm & 1 & 0.03 & 9.24 & $<0.001^{*}$ \\
\hline & Farm period & 3 & 0.07 & 22.28 & $<0.001^{*}$ \\
\hline & $\begin{array}{l}\text { Farm } \times \text { farm } \\
\text { period }\end{array}$ & 3 & 0.0 & 0.51 & 0.67 \\
\hline \multirow[t]{3}{*}{$\mathrm{NH}_{4}^{+}$} & Farm & 1 & 0.01 & 0.84 & 0.36 \\
\hline & Farm period & 3 & 0.08 & 6.53 & $<0.001^{*}$ \\
\hline & $\begin{array}{l}\text { Farm } \times \text { farm } \\
\text { period }\end{array}$ & 3 & 0.01 & 0.82 & 0.48 \\
\hline \multirow[t]{3}{*}{$\mathrm{NO}_{3}^{-}$} & Farm & 1 & 0.01 & 26.26 & $<0.001^{*}$ \\
\hline & Farm period & 3 & 0.01 & 22.47 & $<0.001^{*}$ \\
\hline & $\begin{array}{l}\text { Farm } \times \text { farm } \\
\text { period }\end{array}$ & 3 & 0.01 & 13.18 & $<0.001^{*}$ \\
\hline
\end{tabular}

(Kruskal-Wallis $p=0.04$ and $p=0.03$, respectively). At the BTF, increasing epi-endophyte coverage in $K$. malesianus was moderately correlated with an increase in ice-ice syndrome $(\mathrm{r}=0.34 ; p<0.05)$ and the biofilm coverage in the seaweed thallus $(\mathrm{r}=0.32, p<0.05)$. However, the epi-endophyte coverage in $K$. alvarezii indicated a poor correlation to the incidence of the ice-ice syndrome $(\mathrm{r}=0.22 ; p<0.05)$ (Table 3$)$. At the NBTF, the epi-endophyte coverage in $K$. malesianus and $K$. alvarezii was not correlated with the ice-ice syndrome in both seaweeds (Table 4).

The biofilm coverage in $K$. malesianus between farms was shown to be statistically different (Kruskal-Wallis $p=$ 0.01 ), whilst in $K$. alvarezii there was no significant difference (Kruskal-Wallis $p=0.61$ ). The occurrence of biofilm on the thallus of both species at the BTF averaged $11.99 \pm$ $1.32 \%$ and $4.92 \pm 1.39 \%$, respectively (Fig. 5a, b), whilst at the NBTF the coverage was slightly higher with an average of $17.24 \pm 4.2 \%$ and $5.11 \pm 1.3 \%$, respectively (Fig. $5 \mathrm{c}, \mathrm{d}$ ). The increasing coverage of biofilm on the seaweed thallus at the BTF was poorly correlated with increasing ice-ice incidence in $K$. alvarezii $(\mathrm{r}=0.24)$ and the availability of the epi-endophyte coverage in K. malesianus and K. alvarezii ( $\mathrm{r}$ $=0.32$ and $\mathrm{r}=0.23$, respectively) (Table 3 ).

At the NBTF, the biofilm coverage had poor correlation with the incidence of ice-ice in $K$. alvarezii $(\mathrm{r}=0.18 ; p<$ 0.05 ) (Table 4). Comparison of biosecurity cost and standard cost at two treatment farms is shown in Table 5.

\section{Seaweed quality}

Seaweed quality was measured by the carrageenan yield and gel strength at day 40. At the NBTF, the ice-ice infected thallus of $K$. alvarezii had a higher carrageenan yield in the range of 41.73-57.21\% compared with $K$. malesianus, which had a range of $43.26-52.67 \%$, respectively. The gel strength of these infected thalli indicated a similar pattern, with a range of $180-260 \mathrm{~g} \mathrm{~cm}^{-2}$ and $160-230 \mathrm{~g} \mathrm{~cm}^{-2}$, respectively. The result indicated no significant difference in carrageenan yield $(p=0.57 ; \mathrm{t}=-0.61)$ and gel strength $(p=0.08 ; \mathrm{t}=$ -2.25 ) for both Kappaphycus species related to quality of the infected thalli (Table 6). No comparison was made on the quality of the ice-ice thalli between two treatment farms due to the insufficient weight of infected thalli at the BTF.

The carrageenan yield and gel strength of healthy thalli of $K$. malesianus and $K$. alvarezii at the BTF were higher compared with these species at the NBTF (Table 6). The value of carrageenan yield at the BTF was ranged from
Fig. 4 Temporal variability of inorganic nutrients $\mathrm{NH}_{4}^{+}$and $\mathrm{NO}_{3}{ }^{-}$at the BTF (black colour) and the NBTF (grey colour) during the cultivation period from 18 June to 28 July 2019
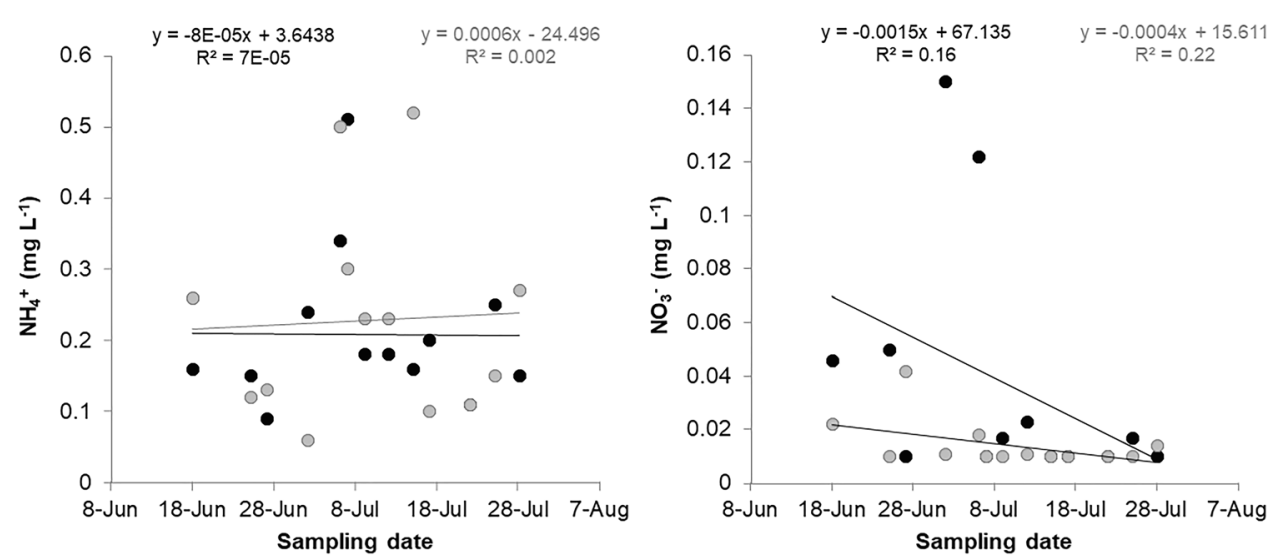
Fig. 5 Variation in coverage of epiphyte, epi-endophyte, biofilm and the incidence of ice-ice syndrome on each species in both farms are shown by a $K$. malesianus at the BTF, b $K$. alvarezii at the BTF, c $K$. malesianus at the NBTF and d $K$. alvarezii at the NBTF a)

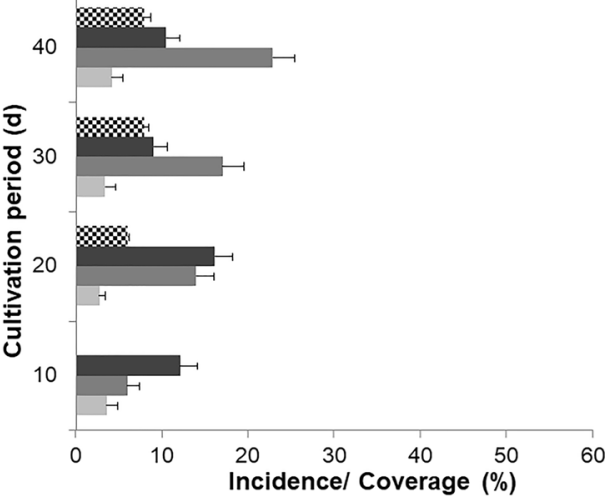

c)

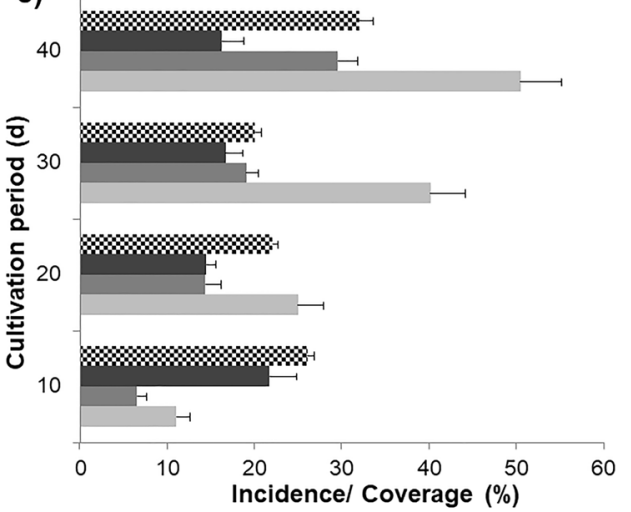

b)

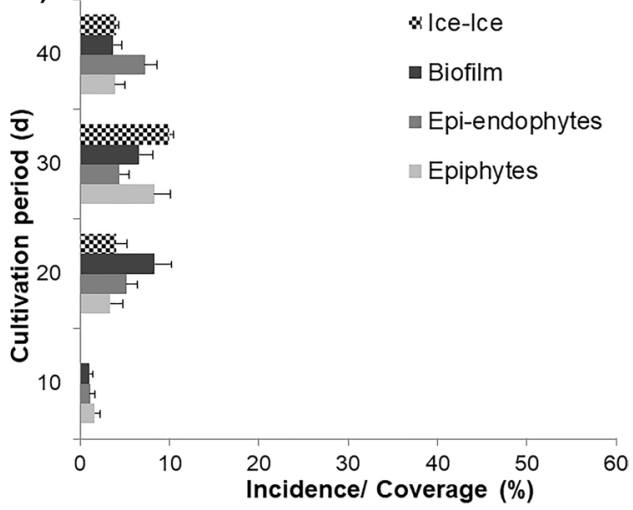

d)

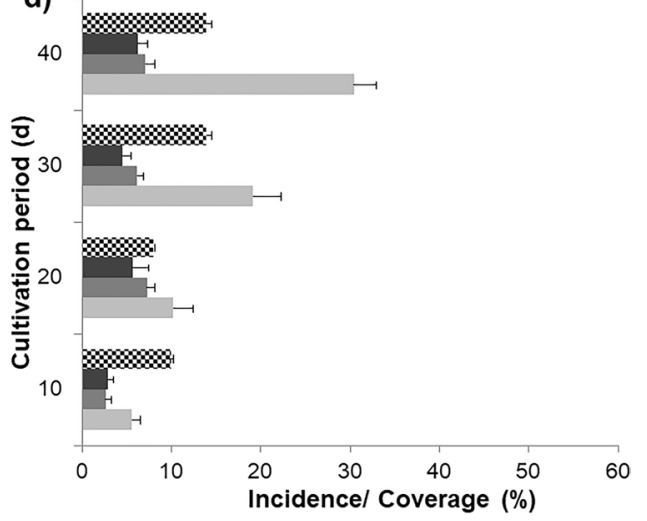

Fig. 6 Bleached thallus caused by ice-ice syndrome and the common bleached tip, as result of air exposure in the early cultivation period: a the epiendophytes Melanothamnus sp. covering rotten bleached thallus of $K$. malesianus at the NBTF at 10 days, $b$ bleached $K$. malesianus at the BTF at 40 days with $70 \%$ epi-endophyte coverage, $\mathbf{c}$ bleached $K$. alvarezii thallus observed at 40 days at the BTF, $\mathbf{d}$ bleached tips in $K$. malesianus at the BTF (scale bar: $3 \mathrm{~cm}$ )

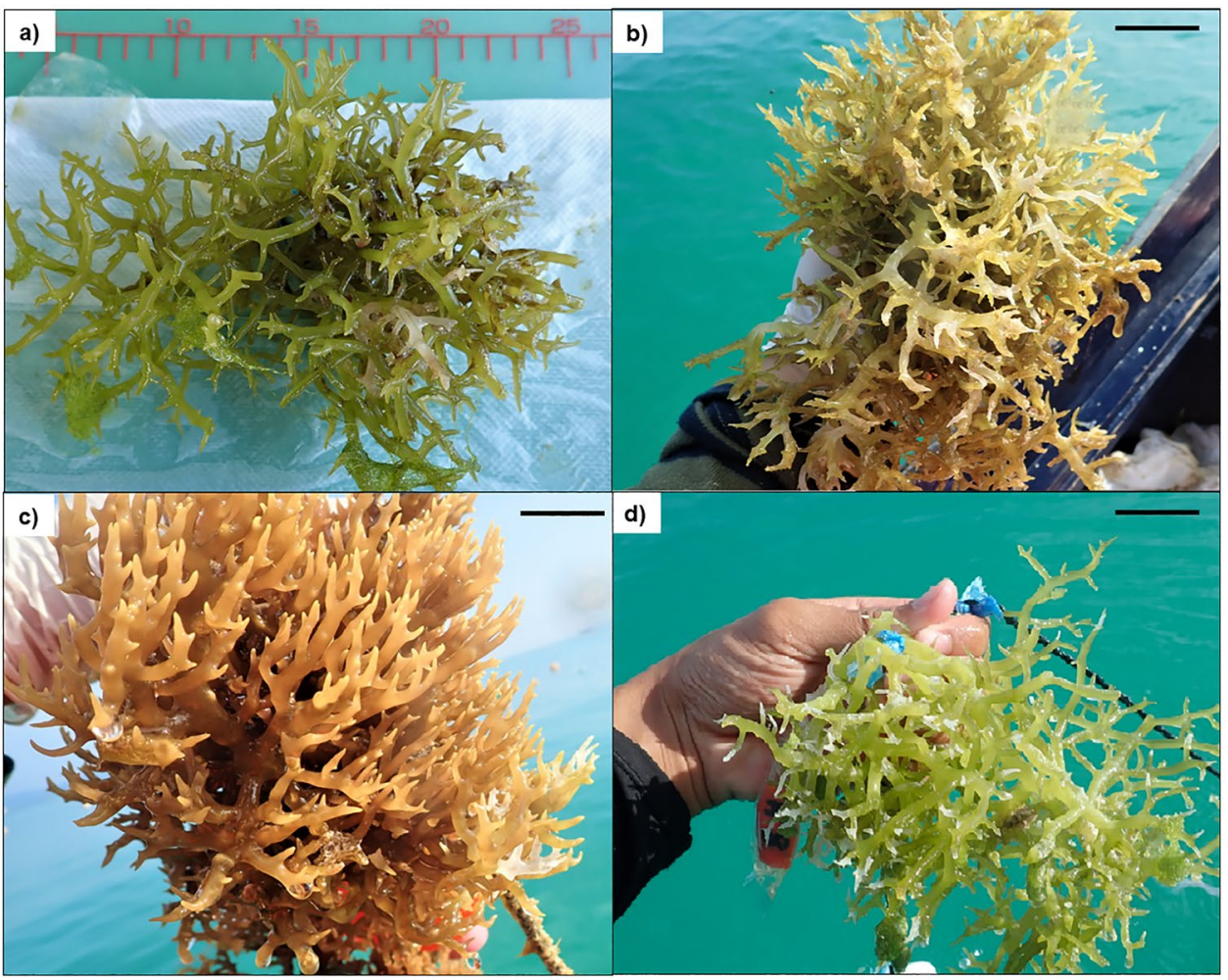


Table 3 Spearman correlation of the pest coverage and the incidences of the ice-ice syndrome in K. malesianus and K. alvarezii at the BTF

\begin{tabular}{|c|c|c|c|c|c|c|c|c|c|c|}
\hline & & & Correlat & & & & & & & \\
\hline & & & IIDKM & EpKM & EЕрКM & BKM & IIDKA & EpKA & EEpKA & BKA \\
\hline Spearman's rho & IIDKM $^{* *}$ & $\begin{array}{l}\text { Correlation coefficient } \\
\text { Sig. (2-tailed) }\end{array}$ & 1.00 & & & & & & & \\
\hline & EpKM & Correlation coefficient & 0.13 & 1.00 & & & & & & \\
\hline & & Sig. (2-tailed) & 0.07 & & & & & & & \\
\hline & EЕpKM & Correlation coefficient & $0.34^{*}$ & $0.14^{*}$ & 1.00 & & & & & \\
\hline & & Sig. (2-tailed) & 0.00 & 0.04 & & & & & & \\
\hline & BKM & Correlation coefficient & 0.13 & 0.03 & $0.32^{*}$ & 1.00 & & & & \\
\hline & & Sig. (2-tailed) & 0.06 & 0.68 & 0.00 & & & & & \\
\hline & IIDKA & Correlation coefficient & 0.04 & $0.16^{*}$ & -0.05 & -0.05 & 1.00 & & & \\
\hline & & Sig. (2-tailed) & 0.55 & 0.02 & 0.51 & 0.45 & & & & \\
\hline & EpKA & Correlation coefficient & 0.06 & 0.04 & 0.07 & 0.07 & $0.18^{*}$ & 1.00 & & \\
\hline & & Sig. (2-tailed) & 0.37 & 0.56 & 0.34 & 0.32 & 0.01 & & & \\
\hline & EEpKA & Correlation coefficient & 0.05 & 0.09 & 0.07 & -0.09 & $0.22^{*}$ & $0.16^{*}$ & 1.00 & \\
\hline & & Sig. (2-tailed) & 0.49 & 0.23 & 0.29 & 0.16 & 0.00 & 0.02 & & \\
\hline & BKA & Correlation coefficient & $0.15^{*}$ & 0.12 & $0.24^{*}$ & 0.03 & $0.24^{*}$ & 0.03 & $0.23^{*}$ & 1.00 \\
\hline & & Sig. (2-tailed) & 0.03 & 0.09 & 0.00 & 0.66 & 0.00 & 0.68 & 0.00 & \\
\hline
\end{tabular}

${ }^{*}$ Correlation is significant at the 0.05 level (2-tailed), $\mathrm{N}=200$

** IIDKM ice-ice syndrome in $K$. malesianus, EpKM epiphytes in $K$. malesianus, EEpKM epi-endophytes in $K$. malesianus, BKM biofilm in $K$. malesianus, IIDKA ice-ice syndrome in $K$. alvarezii, EpKA epiphytes in $K$. alvarezii, EEpKA epi-endophytes in $K$. alvarezii, BKA biofilm in $K$. alvarezii

45.22 to $62.72 \%$ in $K$. malesianus and 46.40 to $70.44 \%$ in K. alvarezii, whilst at the NBTF was ranged from 42.40 to $60.53 \%$ and from 46.44 to $61.87 \%$, respectively. The gel strength in $K$. malesianus and $K$. alvarezii at the BTF ranged from 280 to $450 \mathrm{~g} \mathrm{~cm}^{-2}$ and from 300 to $490 \mathrm{~g} \mathrm{~cm}^{-2}$, respectively, whilst at the NBTF the gel strength ranged from 200 to $300 \mathrm{~g} \mathrm{~cm}^{-2}$ and from 220 to $380 \mathrm{~g} \mathrm{~cm}^{-2}$, respectively. However by t-test statistical analysis, there was no difference

Table 4 Spearman correlation of the pest coverage and the incidences of ice-ice syndrome in K. malesianus and $K$. alvarezii at the NBTF

\begin{tabular}{|c|c|c|c|c|c|c|c|c|c|c|}
\hline & & & Correlati & & & & & & & \\
\hline & & & IIDKM & EpKM & EEpKM & BKM & IIDKA & EpKA & EEpKA & BKA \\
\hline Spearman's rho & IIDKM & $\begin{array}{l}\text { Correlation coefficient } \\
\text { Sig. (2-tailed) }\end{array}$ & 1.00 & & & & & & & \\
\hline & EpKM & Correlation coefficient & 0.11 & 1.00 & & & & & & \\
\hline & & Sig. (2-tailed) & 0.12 & & & & & & & \\
\hline & EЕpKM & Correlation coefficient & 0.06 & $0.39^{*}$ & 1.00 & & & & & \\
\hline & & Sig. (2-tailed) & 0.42 & 0.00 & & & & & & \\
\hline & BKM & Correlation coefficient & 0.05 & 0.02 & -0.01 & 1.00 & & & & \\
\hline & & Sig. (2-tailed) & 0.44 & 0.78 & 0.85 & & & & & \\
\hline & IIDKA & Correlation coefficient & -0.01 & 0.09 & 0.01 & 0.09 & 1.00 & & & \\
\hline & & Sig. (2-tailed) & 0.88 & 0.18 & 0.89 & 0.22 & & & & \\
\hline & EpKA & Correlation coefficient & 0.13 & $0.29^{*}$ & $0.39^{*}$ & -0.05 & $0.14^{*}$ & 1.00 & & \\
\hline & & Sig. (2-tailed) & 0.06 & 0.00 & 0.00 & 0.47 & 0.04 & & & \\
\hline & EEpKA & Correlation coefficient & -0.10 & 0.20 & 0.05 & -0.02 & 0.03 & 0.11 & 1.00 & \\
\hline & & Sig. (2-tailed) & 0.15 & 0.00 & 0.45 & 0.75 & 0.66 & 0.12 & & \\
\hline & BKA & Correlation coefficient & 0.09 & 0.07 & 0.14 & 0.09 & $0.18^{*}$ & 0.12 & 0.08 & 1.00 \\
\hline & & Sig. (2-tailed) & 0.19 & 0.31 & 0.06 & 0.22 & 0.01 & 0.09 & 0.29 & \\
\hline
\end{tabular}

* Correlation is significant at the 0.05 level (2-tailed), $\mathrm{N}=200$ 
Table 5 Comparison of biosecurity and standard cost at two treatment farms

\begin{tabular}{lll}
\hline Variable cost & Standard cost & Biosecurity cost \\
\hline Propagule cost & 14.40 & 14.40 \\
Labour cost & 7.20 & 7.20 \\
Additional labour cost (for & - & 144 \\
$\quad$ cleaning treatment) & & \\
Equipment \& consumable cost & $112^{\mathrm{a}}$ & $280^{\mathrm{b}}$ \\
Total cost & 133.60 & 445.60 \\
Number of healthy bundles & 77 & 94 \\
Cost per bundle & 1.74 & 4.49 \\
\hline
\end{tabular}

Standard cost applied at NBTF (in USD; 1 MYR =0.24 USD)

Biosecurity cost applied at BTF (in USD)

${ }^{\text {a }}$ Standard cost for equipment \& consumable includes purchasing ropes and buoys, and boat rental

${ }^{\mathrm{b}}$ Biosecurity cost for equipment \& consumable includes additional cost for purchasing the cleaning tools, extra boat rental for regular cleaning activities, and all standard cost

Table 6 Comparison of mean carrageenan yield, gel strength of $K$. malesianus and $K$. alvarezii in relation to thallus condition at the BTF and the NBTF

\begin{tabular}{|c|c|c|c|}
\hline Variable & BTF & NBTF & $p$ value \\
\hline \multicolumn{4}{|l|}{ K. malesianus healthy thallus } \\
\hline Carrageenan yield (\%) & $52.72 \pm 2.9$ & $47.39 \pm 1.7$ & $p=0.20$ \\
\hline Gel strength $\left(\mathrm{g} \mathrm{cm}^{-2}\right)$ & $330 \pm 16.4$ & $270 \pm 9.9$ & $p=0.00$ \\
\hline \multicolumn{4}{|l|}{ K. alvarezii healthy thallus } \\
\hline Carrageenan yield (\%) & $60.57 \pm 2.0$ & $53.08 \pm 1.3$ & $p=0.13$ \\
\hline Gel strength $\left(\mathrm{g} \mathrm{cm}^{-2}\right)$ & $370 \pm 13.5$ & $310 \pm 11.7$ & $p=0.01^{*}$ \\
\hline Ice-ice thallus & K. malesianus & K. alvarezii & \\
\hline Carrageenan yield (\%) & $48.25 \pm 1.5$ & $51.88 \pm 2.6$ & $p=0.57$ \\
\hline Gel strength $\left(\mathrm{g} \mathrm{cm}^{-2}\right)$ & $180 \pm 10.0$ & $210 \pm 13.1$ & $p=0.08$ \\
\hline
\end{tabular}

*Significant value at the 0.05 level, healthy thallus $n=20$; ice-ice thallus $n=5$ in carrageenan yield in the healthy thallus between farms of $K$. alvarezii $(p=0.13 ; \mathrm{t}=1.56)$ and $K$. malesianus $(p=$ $0.20 ; \mathrm{t}=1.32)$, whilst the gel strength showed a significant difference of the two species between farms $(p=0.01 ; \mathrm{t}=$ 3.21 and $p=0.00 ; \mathrm{t}=4.32$ ), respectively.

The SGR of $K$. malesianus and $K$. alvarezii cultivated at the BTF demonstrated high growth rates for the period $10-20$ days, with rates ranging from 0.43 to $8.37 \%$ day $^{-1}$ and from 0.66 to $9.87 \% \mathrm{day}^{-1}$, respectively. At the NBTF, the SGR of $K$. malesianus and $K$. alvarezii ranged from 0.63 to $5.76 \%$ day $^{-1}$ and from 0.82 to $6.25 \%$ day $^{-1}$, respectively. The SGR of the two seaweed species was significantly higher at the BTF compared with the NBTF $(p<0.05 ; \mathrm{F}=18.05$ and $p<0.05 ; \mathrm{F}=13.08$, respectively, Fig. 7). However, with continuously decreasing SGR in each growth period, the statistical analysis confirmed that the interaction between farm periods and farms in $K$. malesianus and $K$. alvarezii did not show any significant difference $(p=0.92 ; \mathrm{F}=0.16$ and $p=0.12: \mathrm{F}=1.96$, respectively; Table 7).

\section{Identification of farm biosecurity risk}

The identification of potential risks related to ice-ice syndrome and pest outbreaks at the Kappaphycus farm revealed risk hazards from the farm preparation stage, to grow-out and harvesting stages at the two treatment farms (Table 8). The potential risks at the farm preparation stage included a lack of water movement in the initial farming period, low salinity levels, interference of herbivorous grazers and epiendophytes attached to the propagules, desiccation of propagules in the initial stage, a lack of disinfecting and cleaning of farm equipment, pollution of the surrounding area with municipal waste and the influence of epiphyte blooms. In the grow-out phase, the potential risks included initial propagules with desiccated thallus leading to bleached tips and wounds, fast growth of epiphytes and epi-endophytes on thallus and ropes, discarded bleached and/or infected thallus and pests not removed from the grow-out area and a lack of
Fig. 7 Variability of the SGR of seaweed: a K. malesianus and $\mathbf{b}$ $K$. alvarezii at the BTF and the NBTF
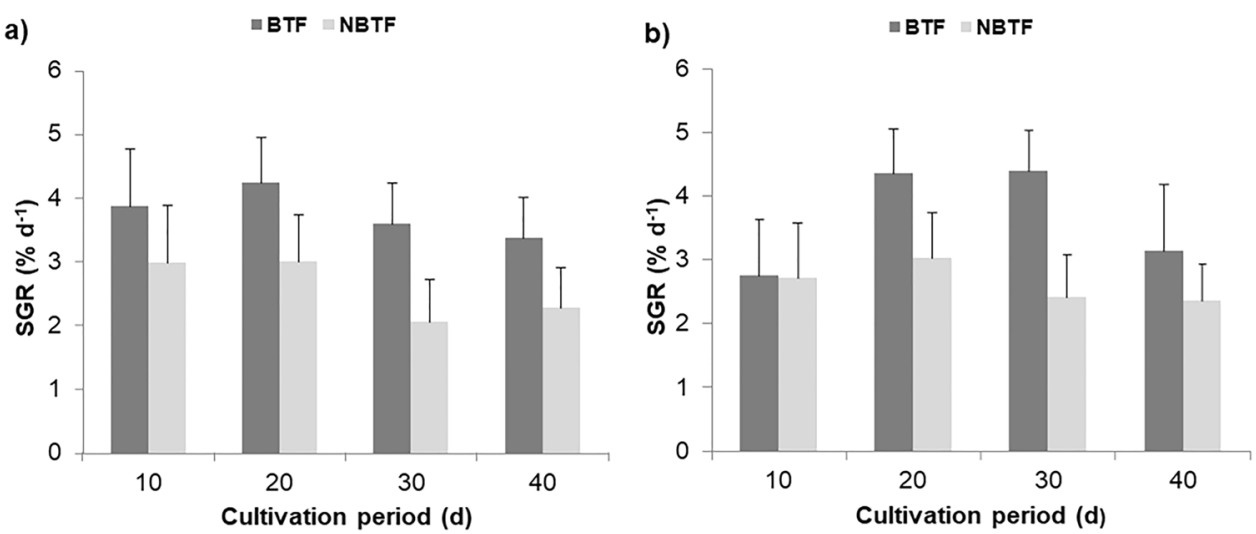
Table 7 Two-way ANOVA on the SGR of K. malesianus and K. alvarezii between farms and farm periods

\begin{tabular}{llllll}
\hline Variable & $\begin{array}{l}\text { Source of } \\
\text { variation }\end{array}$ & Df & Mean square & F value & $p$ value \\
\hline K. malesianus & Farm & 1 & 56.33 & 18.05 & $<0.001^{*}$ \\
& Farm period & 3 & 7.02 & 2.25 & 0.08 \\
& $\begin{array}{l}\text { Farm } \times \text { farm } \\
\text { period }\end{array}$ & 3 & 0.50 & 0.16 & 0.92 \\
K. alvarezii & Farm & 1 & 46.54 & 13.08 & $<0.001^{*}$ \\
& Farm period & 3 & 8.54 & 2.39 & 0.07 \\
& Farm $\times$ farm & 3 & 7.00 & 1.96 & 0.12 \\
& period & & & & \\
\hline
\end{tabular}

*Significant value at the 0.05 level, $n=20$

cleaning on the thallus and ropes. The harvest stage had the lowest potential risk to the seaweed cultivation process, but a high risk was identified to the wider environment system, if the farm was left unmanaged. In addition, there was no clear information regarding the migration route for the turtles-a major grazer of cultivated seaweeds, no regular monitoring and control of the on-farm systems by the competent authority, limited availability of healthy propagules for cultivation purposes and a lack of evidence on whether ice-ice syndrome can be moved through the transfer of equipment between farms.

\section{Discussion}

\section{Controlling the ice-ice syndrome}

This study has demonstrated for the first time that biosecurity measures, including both preventative and detection approaches to limit coverage of epiphytes, epi-endophytes and biofilm also lowered the incidence of ice-ice syndrome in Kappaphycus farm. These biosecurity measures produced a disease-free crop (up to $96 \%$ ) throughout the entire culture period. In contrast, the incidence of the ice-ice syndrome was more than $3 \times$ the levels on the farm without the additional biosecurity measures, in which a third of the crop was infected by the end of the culture period. Understanding the pest species composition and their temporal occurrence can, therefore, give an advantage for farm management, in terms of predicting the extent of the risk impact and the mitigation process (Walls et al. 2017). This study confirmed that macroalgae epiphytes and filamentous epi-endophytes were dominant seaweed pests at the study site and by removing these pests consistently, the causative agents of the ice-ice syndrome were removed from the farm system.

This manual cleaning method, therefore, provides the first evidence to support the numerous studies that have suggested this as a potential method to reduce outbreaks of the ice-ice syndrome (Vairappan et al. 2010; WWF 2014; Kim et al. 2017; Largo et al. 2020). This method though does lead to high labour costs in pest removal and may become an obstacle to the implementation of this technique by the seaweed farmer. However, the cost-effectiveness of biosecurity measures could balance the additional cost against the higher quality crop that is produced (Hester and Cacho 2017). This study confirmed that manual cleaning methods, albeit time-consuming, are an effective management measure in eucheumatoid farming and should be taken into account when developing best farming practices to control farm risk related disease management strategies, although long-term investment and incentives would also be required (Fasina et al. 2012; Cottier-Cook et al. 2016; Scarfe and Palić 2020).

\section{Controlling the pests outbreak}

Several macroalgae such as Laurencia spp., Chaetomorpha spp., Cladophora spp., Ceramium spp., Acanthopora spp. and Ulva spp. were regularly attached to the thallus with various coverage rates from 30 to $100 \%$ in $K$. malesianus and 25 to $80 \%$ in $K$. alvarezii, in addition to the farm ropes. Our study demonstrated that the abundance of macroalgae epiphytes covering $K$. malesianus and $K$. alvarezii was not strongly linked to the incidence of ice-ice syndrome in both species. However, the correlation analysis showed a similar pattern between the occurrence of macroalgae epiphytes and the ice-ice syndrome in $K$. alvarezii. There are several factors that may trigger the ice-ice syndrome in Kappaphycus due to the presence of epiphytic macroalgae (Vairappan et al. 2010; Potin 2012; Ingle et al. 2018; Sahu et al. 2020). Firstly, the epiphytic macroalgae (e.g., Ulva sp. and Cladophora sp.) may hinder host growth through competition for biological resources, such as light, nutrients and carbon, thus weakening the condition of the thallus based upon the extent of their coverage (Potin 2012; Largo et al. 2020; Kambey et al. 2020b; Sahu et al. 2020). Secondly, the abundance of macroalgae epiphytes (e.g. Laurencia sp. and Acanthopora sp.) may act as a transmission route for the microscopic pathogenic agents that cause ice-ice syndrome (Vairappan et al. 2010; Ingle et al. 2018). Thirdly, high inorganic $\mathrm{NH}_{4}{ }^{+}$and $\mathrm{NO}_{3}{ }^{-}$concentrations in the surrounding farm area (up to $0.52 \mathrm{mg} \mathrm{L}^{-1}$ and $0.15 \mathrm{mg} \mathrm{L}^{-1}$, respectively) has been shown to facilitate epiphyte and epi-endophyte blooms, whilst a low water current $<0.1 \mathrm{~m} \mathrm{~s}^{-1}$ may have enabled the elevated biofilm coverage, which may have enabled the attachment of the pathogenic microorganisms to the thallus surface. By removing the macroalgae epiphytes and biofilm, therefore, the incidence of ice-ice syndrome in both species can be controlled. 


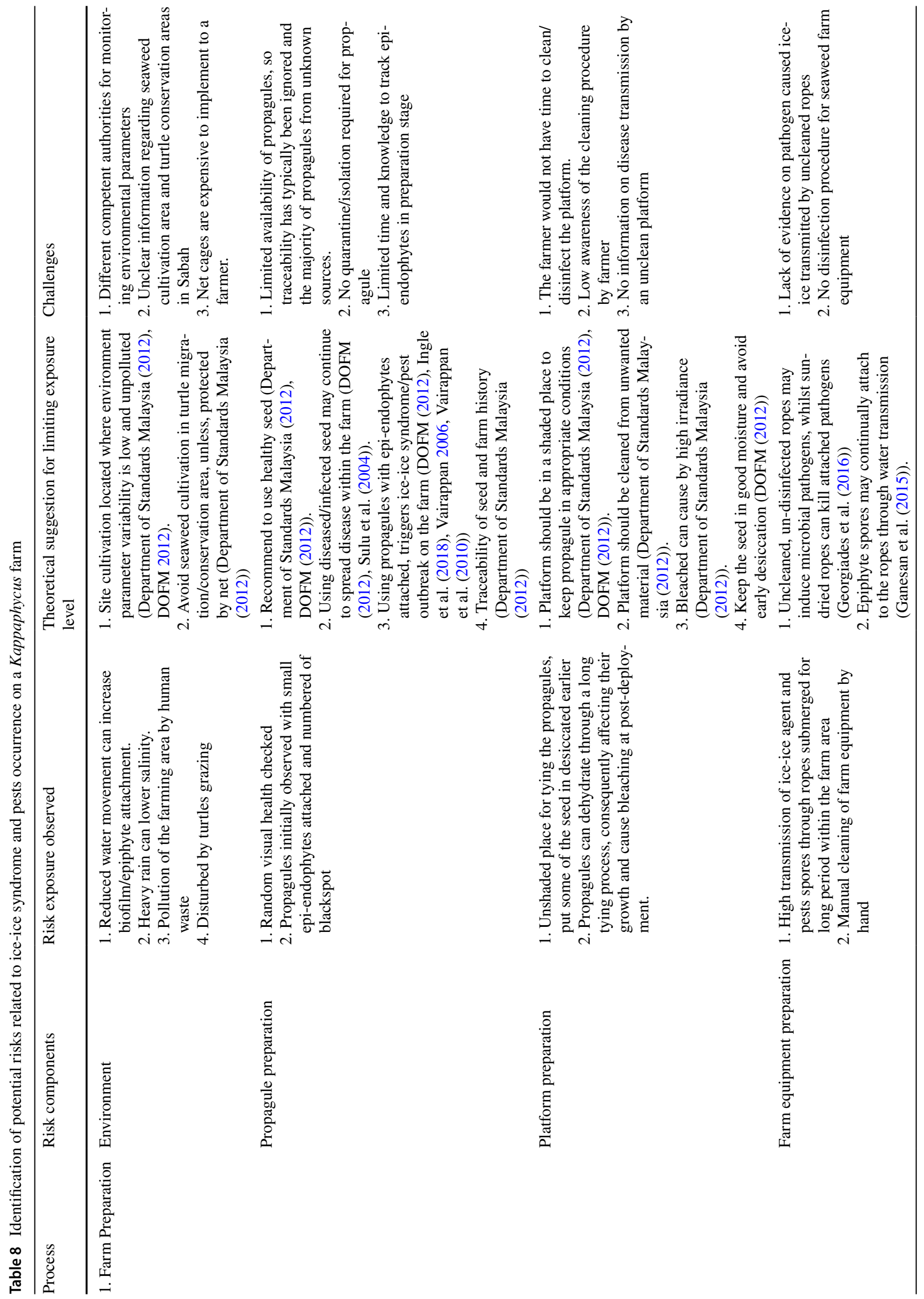




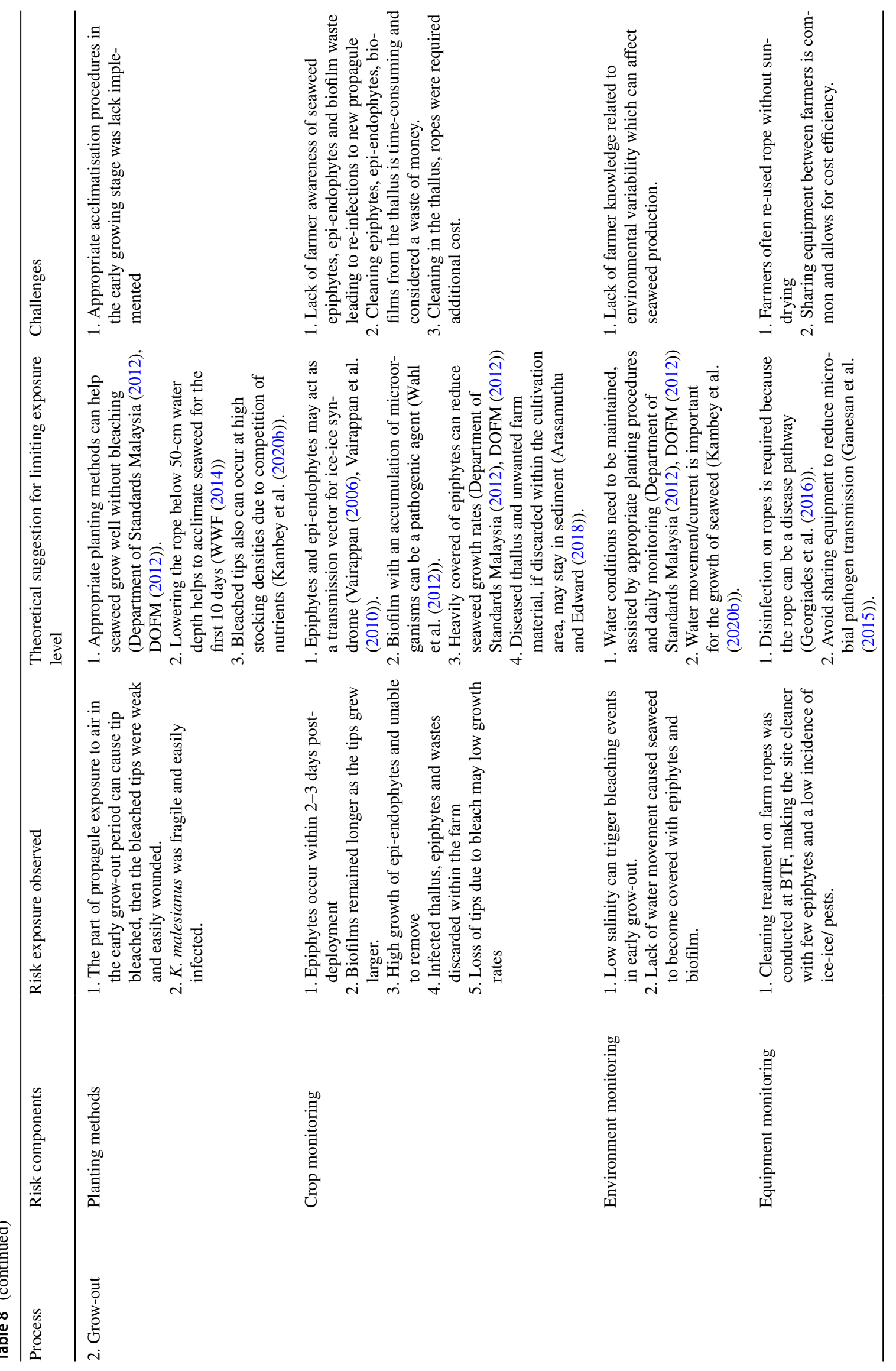


In contrast, the cleaning method was not effective in removing the epi-endophytes, particularly the commonly occurring filamentous alga Melanothamnus sp. (formerly known as Neosiphonia sp.), which was found in the majority of the bleached thallus of $K$. malesianus at both farms. The results showed that the occurrence of the epiendophytes was significantly related to the presence of ice-ice syndrome, as reported in other studies (Vairappan et al. 2008; Pang et al. 2015; Tsiresy et al. 2016; Hurtado et al. 2019). Melanothamnus rhizoids can penetrate deep into the cortex and the medullary tissue of the Kappaphycus thallus and subsequently can facilitate secondary bacterial infection (Vairappan 2006; Vairappan et al. 2008). This process leads to tissue bleached and thallus disintegration (Leonardi et al. 2006; Tsiresy et al. 2016). In addition, $K$. malesianus propagules used in this study were covered by numerous black spots and were the first to show signs of infection by Melanothamnus sp. (Vairappan 2006; Tsiresy et al. 2016). These black spots are commonly observed in late February to June in eucheumatoid farms in Sabah and both Kappaphycus species are often exposed to this epi-endophyte (Vairappan 2006; Ali et al. 2020). A strict quarantine protocol, whilst transporting seaweed propagules between areas should, therefore, be regularly practiced by the farmers and monitored by the competent authority, to reduce the risk of introduction and spread of this damaging pest. Initial inspection of the health status of the propagules, including of presence of the black spot in the thallus, should be routinely practiced as a precaution to minimise the spread of disease and pests. A lack of detection in the initial stage of this study was assumed to be responsible for the heavy infestations of Melanothamnus sp. in both farms and species, particularly in $K$. malesianus which indicated to have less resistance to this pest compared with $K$. alvarezii.

The biofilm attached to the Kappaphycus thallus, however, was not found to have any strong influence on the occurrence of the ice-ice syndrome, irrespective of seaweed species and whether biosecurity measures were present or not. However, the biofilm attached to the Kappaphycus thallus was correlated with increasing epi-endophyte growth. Previous studies have confirmed that biofilms can be detrimental for seaweeds due to their aggregation of pathogenic microorganisms and settlement spores of the various pests (Wahl et al. 2012; Potin 2012; Tsiresy et al. 2016), as well as infectious bacteria causing ice-ice syndrome (Arasamuthu and Edward 2018; Kopprio et al. 2021). In this study, the biofilms, irrespective of the cultivation period, were easily removed by regular farm cleaning. A study by Pang et al. (2015) confirmed that water currents greater than $0.1 \mathrm{~m} \mathrm{~s}^{-1}$ were able to keep the thallus clean from the biofilms; however, the effect of interactions between the biofilm and the host seaweed is largely thought to be host-specific (Lachnit et al. 2009; Mancuso et al. 2016). 


\section{Improvement in seaweed quality}

The implementation of biosecurity measures on the Kappaphycus farm led to a significantly higher quality seaweed crop. Numerous studies have previously reported that a thallus with the ice-ice syndrome and high epiphyte and epi-endophyte coverage had reduced seaweed quality compared with healthy (i.e. no ice-ice infection or pest coverage) thallus (Mendoza et al. 2002; Vairappan et al. 2014; Yong et al. 2014; Periyasamy et al. 2016). This study reported that ice-ice infected and uncleaned thallus have a $10-14 \%$ reduction in carrageenan yield and $16-45 \%$ reduction in gel strength compared with healthy thallus produced by the farm with biosecurity measures. The ranges of carrageenan yield and gel strength from healthy Kappaphycus in this study were similar to those found for healthy Kappaphycus in previous studies (53-62\% and 193-650 $\mathrm{g} \mathrm{cm}^{-2}$, respectively) (Mendoza et al. 2002; Luhan et al. 2015; Ali et al. 2020). With high carrageenan yield and gel strength reported, this study demonstrated that biosecurity measures involving the cleaning and removal of pests, improved seaweed quality and thus, would influence the market price of the seaweed. Interestingly, this study also found that 'healthy' $K$. alvarezii had a better carrageenan quality and gel strength compared with healthy K. malesianus.

The SGR of the two Kappaphycus species was higher in the biosecurity farm compared with farms without biosecurity measures. A reduction in the growth rate of seaweed grown on the farm without biosecurity measures was correlated with the high incidence of the ice-ice syndrome, which disintegrated the main or secondary thallus (Hurtado et al. 2019). To promote high growth rates and to avoid ice-ice syndrome, it is therefore advised, that knowledge of early detection and how to prevent the introduction of causative agents, particularly at the propagule preparation stage, should be recommended to farmers and included in any farming best practice guidelines.

\section{Environmental influences on ice-ice syndrome and pests}

In general, certain environment parameters can significantly increase the risk of an ice-ice or pest outbreak. Regular environmental monitoring has been shown to limit the farm risk related to ice-ice and pest outbreaks since, for example ice-ice syndrome has been shown to occur seasonally (Vairappan et al. 2008, 2014; Pang et al. 2015; Ward et al. 2020). Numerous experiments have also shown that extreme temperatures, heatwaves, high fluctuations in salinity, high light intensity, low water current and lack of water movement can trigger ice-ice syndrome in Kappaphycus species (Largo et al. 1995, 2020;
Vairappan et al. 2010; Kambey et al. 2020b). In this study, high seawater temperatures up to $30.6{ }^{\circ} \mathrm{C}$, coupled with low water movement (average $<0.10 \mathrm{mg} \mathrm{L}^{-1}$ ), may have stressed the seaweed to uptake the nutrients for photosynthesis and growth (Luhan et al. 2015; Kambey and Chung 2016; Roleda and Hurd 2019; Kambey et al. 2020b, c). In addition, the high variability in salinity in the study area may have increased the stress on the thallus (Pang et al. 2015). Consequently, a weakening of the thallus may have increased the susceptibility of the thin epidermis layer of $K$. malesianus to the pest Melanothamnus sp. compared with $K$. alvarezii.

Our findings have demonstrated that almost all environmental parameters measured in both farms were similar in value and concentration, with the exception of $\mathrm{pH}$ and inorganic $\mathrm{NO}_{3}{ }^{-}$, but the incidence of ice-ice and pest coverage between farms was significantly different. Increasing temperature and nutrient concentrations, together with low water current/movement though may be associated with the 'ice-ice-season' in Malaysia. Site selection and regular environmental monitoring are, therefore, extremely important to enable farmers to manage their farm and production more effectively year-round.

\section{Farm risks identification}

The assessment of biosecurity-related risk on a 'typical' Kappaphycus farm provides insight into the potential management-based biosecurity measures from the preparation, grow-out to the harvesting stage. No isolation or local quarantine procedures were observed following the arrival of the new propagules prior to deployment on the farm. In the current study, the health condition of the propagules was only superficially assessed visually. Studies have shown, however, that many pests are microscopic, including the epi-endophyte Melanothamnus sp., (e.g., appearance as black spot), which has spores that reside inside the thallus (Vairappan 2006; Tsiresy et al. 2016; Largo et al. 2020). This stage of the process, therefore, was considered as high risk in terms of biosecurity, even though the propagules were purchased from an 'ice-ice-free' or 'less infected' area. Isolation of the new propagule may, therefore, be an important initial preventative measure to detect any occurrence of ice-ice syndrome or pests to reduce the contamination risk (Sulu et al. 2004; DOFM 2012; Araujo et al. 2020).

The propagule preparation time was also identified as a high risk for the ice-ice syndrome, due to potential desiccation of the thallus. In this study, longer air exposure prior to the deployment stage led to tip bleaching and thallus fragmentation in the early cultivation period. Equipment, particularly ropes, was also highlighted as high risk for introducing or spreading the causative agents of the ice-ice syndrome and pests on the farm (Ganesan et al. 2015; Tsiresy 
et al. 2016). The use of natural disinfectant processes, such as sun-drying for farm equipment and ropes is, therefore, recommended to de-activate the pathogenic organisms (Rodgers et al. 2015; Georgiades et al. 2016), and to reduce the operational costs of buying new equipment (Department of Standards Malaysia 2012). New ropes were used in this study, but without cleaning treatment, the occurrence of ice-ice syndrome on Kappaphycus seaweed was found high. The disinfection process followed by cleaning treatment, therefore, should be a standard requirement as a biosecurity measure in Kappaphycus farms.

In the grow-out phase, this study recommends the removal of infected thallus and pests, and their disposal in landfill and not into the adjacent water, as usually practiced by the farmer. This biosecurity measure should be considered as a high priority in farm management to avoid the likelihood of spreading pathogenic agents to other parts of the farm or underlying sediment (Pang et al. 2015; Ganesan et al. 2015; Arasamuthu and Edward 2018; Campbell et al. 2019). In addition, the farmers often re-used the healthy part of the infected and bleached thalli as new propagules for the next cycle without any detection measures (Farmer, M. Bangkoko, pers. comm). This practice could explain why the ice-ice syndrome and pest infestation have propagated from one to another farm. In the harvest stage, the farmers also often mix the infected with the healthy thallus at the post-harvest processing stage, which can lower the end-product quality. This inadequate practice can reduce the market purchasing price and affect the farmer-buyer relationship (Mariño et al. 2019; Nor et al. 2020). Therefore, incentives will need to be provided by the competent authority to enable the new recommendations to be fully implemented.

Effective biosecurity measures should, therefore, require a comprehensive understanding of every stage in the farming process, including the introduction pathways of the caustic agents for ice-ice syndrome and pests. The critical control points on the Kappaphycus farm should be identified to inform management decisions, particularly in an industry such as eucheumatoid farming, which currently has minimal biosecurity-related policy and guidance (Mateo et al. 2020; Rusekwa et al. 2020; Kambey et al. 2020a).

\section{Conclusions}

This study investigated the application of biosecurity measures in a commercial seaweed Kappaphycus farm. To our knowledge, this work represents the first study to assess the use of biosecurity measures to reduce ice-ice syndrome and pest outbreaks on a commercial Kappaphycus farm. The results from this study highlighted four contributing factors in heightening the risk of an ice-ice or pest outbreaks including (1) lack of propagule monitoring (early detection and preventative treatment of the epi-endophytes) in the preparation stage, (2) lack of cleaning the farm ropes and crop from pests and bleached thallus, (3) reduced water motion/ current and (4) discarding of the pests and the infected thallus into the water column. This lack of a 'whole system' biosecurity approach has resulted in a significant decline in general production and crop quality on seaweed Kappaphycus farms in Malaysia and across South-East Asia. Employing relatively simple cleaning methods to remove the macroalgal epiphytes and biofilm on the seaweed thallus and ropes, in combination with quarantine procedures to detect filamentous epi-endophytes and throughout the entire cultivation period, either in the normal or 'ice-ice season', can lead to a significant reduction in the incidence of the ice-ice syndrome and pests on the farm. Further studies though are recommended to determine the optimum farm site and seasonal variations in biosecurity measures, as well as, conducting a full cost-benefit analysis of these biosecurity measures to strengthen the supportive evidence-base so that these measures can be replicated and scaled up across the Kappaphycus industry nationally and globally.

Acknowledgements The authors would like to acknowledge to Global SeaweedSTAR Malaysian Team, Fisheries officer for the Semporna area and Mr. M Bangkoko (seaweed farmer) who assisted the authors during fieldwork.

Funding This work was part of the GlobalSeaweedSTAR project supported by the UK Research and Innovation - Global Challenge Research Fund (GCRF), Biotechnology and Biological Sciences Research Council Grant 2017 No. BB/PO27806/1; University of Malaya Grant No. IF015-2019 and Higher Center of Excellence (HiCoE) grant funded by the Ministry of Higher Education IOES-2014H.

Open Access This article is licensed under a Creative Commons Attribution 4.0 International License, which permits use, sharing, adaptation, distribution and reproduction in any medium or format, as long as you give appropriate credit to the original author(s) and the source, provide a link to the Creative Commons licence, and indicate if changes were made. The images or other third party material in this article are included in the article's Creative Commons licence, unless indicated otherwise in a credit line to the material. If material is not included in the article's Creative Commons licence and your intended use is not permitted by statutory regulation or exceeds the permitted use, you will need to obtain permission directly from the copyright holder. To view a copy of this licence, visit http://creativecommons.org/licenses/by/4.0/.

\section{References}

Ali MKM, Critchley AT, Hurtado AQ (2020) The impacts of AMPEP $\mathrm{K}+$ (Ascophyllum marine plant extract, enhanced with potassium) on the growth rate, carrageenan quality, and percentage incidence of the damaging epiphyte Neosiphonia apiculata on four strains of the commercially important carrageenophyte Kappaphycus, as developed by micropropagation techniques. J Appl Phycol 32:1907-1916 
Arasamuthu A, Edward JKP (2018) Occurrence of ice-ice disease in seaweed Kappaphycus alvarezii at Gulf of Mannar and Palk Bay, Southeastern India. Indian J Geo-Marine Sci 47:1208-1216

Araujo PG, Nardelli AE, Gelli VC, Fujii MT, Chow F (2020) Monitoring environment risk of the exotic species Kappaphycus alvarezii (Rhodophyta) after two decades of introduction in Southestern Brazil. Bot Mar 63:551-558

Azanza RV, Ask EI (2017) Reproductive biology and ecophysiology of farmed Kappaphycus and Eucheuma. In: Hurtado AQ, Chritchley AT, Neish IC (eds) Tropical seaweed farming trends, problems and opportunities: focus on Kappaphycus and Eucheuma. Springer, Cham, pp 45-53

Bondad-Reantaso MG, Sumption K, Subasinghe R, Lawrence M, Berthe F (2018) Progressive management pathway to improve aquaculture biosecurity (PMP/AB)1. FAO Aquac Newslett 58:9-11

Campbell I, Macleod A, Sahlmann C, Neves L, Funderud J, Overland M, Hughes AD, Stanley M (2019) The environmental risks associated with the development of seaweed farming in Europeprioritizing key knowledge gaps. Front Mar Sci 6:1-22

Campbell I, Kambey CSB, Mateo JP, Rusekwa SB, Hurtado AQ, Msuya FE, Stentiford G, Cottier-Cook EJ (2020) Biosecurity policy and legislation for the global seaweed aquaculture industry. J Appl Phycol 32:2133-2146

Chung IK, Sondak CFA, Beardall J (2017) The future of seaweed aquaculture in a rapidly changing world. Eur J Phycol 52:495-505

Cottier-Cook EJ, Nagabhatla N, Badis Y, Campbell M, Chopin T, Dai W, Fang J, He P, Hewitt C, Kim GH, Huo Y, Jiang Z, Kema G, Li X, Liu F, Liu H, Lu Q, Luo Q, Mao Y, Msuya FE, Rebours C, Shen H, Stentiford GD, Yarish C, Wu H, Yang Z, Zhang J, Zhou Y, Gachon CMM (2016) Safeguarding the future of the global seaweed aquaculture industry. United National University (INWEH) and Scottish Association for Marine Science Policy Brief. ISBN 978-92-808-6080 pp 1-12

Department of Standards Malaysia (2012) Seaweed cultivation-code of practices MS No. 2467. Standards Malaysia 2012. 6 pp

DOFM (2012) Manual pengkulturan rumpai laut (Kappaphycus/ Eucheuma). Jabatan Perikanan Malaysia. $66 \mathrm{pp}$

DOFM (2020) Portal Resmi Jabatan Perikanan. Department Fisheries Malaysia. https://www.dof.gov.my (Visit 7 Sept, 2020)

Duarte CM, Wu J, Xiao X, Bruhn A, Krause-Jensen D (2017) Can seaweed farming play a role in climate change mitigation and adaptation? Front Mar Sci 4:1-8

Eranza DR, Bahron A, Alin J, Mahmud R, Malusirang S (2017) On going assessment of issues in the seaweed farming industry in Sabah, Malaysia. J Asian Acad Appl Bus 4:49-60

FAO (2020) The State of World Fisheries and Aquaculture 2020. Sustainability in action. Rome, $206 \mathrm{pp}$

Fasina FO, Ali AM, Yilma YM, Thieme O, Ankers P (2012) The costbenefit of biosecurity measures on infectious disease in the Egyptian household poultry. Prev Ved Med 103:178-191

Ganesan M, Selvaraj K, Chithra K, Sirajudeen S (2015) Epiphytism differences in Gelidiella acerosa cultivated with floating rafts and concrete blocks. J Appl Phycol 27:399-412

Georgiades E, Fraser R, Jones B (2016) Options to strengthen on-farm biosecurity management for commercial and non-commercial aquaculture. Prepared for the Aquaculture Unit, Ministry for Primary Industries. MPI Technical Paper No: 2016/47. 360 pp

Hester SM, Cacho OJ (2017) The contribution of passive surveillance to invasive species management. Biol Invasions 19:737-748

Hurtado AQ, Neish IC, Critchley AT (2019) Phyconomy: the extensive cultivation of seaweeds, their sustainability and economic value, with particular reference to important lessons to be learned and transferred from the practice of eucheumatoid farming. Phycologia 58:472-483
Ingle KN, Polikovsky N, Chemodanov A, Golberg A (2018) Marine integrated pest management (MIPM) approach for sustainable seagriculture. Algal Res 29:223-232

Kambey C, Chung IK (2016) A stella model for evaluating the efficiency of integrated multi-tropic aquaculture system (IMTA). Aquacult Indo 16:38-49

Kambey CSB, Campbell I, Sondak CFA, Nor ARM, Lim PE, CottierCook EJ (2020) An analysis of the current status and future of biosecurity frameworks for the Indonesian seaweed industry. J Appl Phycol 32:2147-2160

Kambey CSB, Sondak CFA, Chung IK (2020b) Potential growth and nutrient removal of Kappaphycus alvarezii in a fish floating-net cage system in Sekotong Bay, Lombok, Indonesia. J World Aquacult Soc 51:944-959

Kambey CSB, Kang JW, Chung IK (2020c) Impact of temperature, low $\mathrm{pH}$ and $\mathrm{NH}_{4}{ }^{+}$enrichment on ecophysiological responses of a green tide species Ulva australis Areschoug. Ocean Sci J 55:115-127

Kaur CR, Ang MGH (2009) Seaweed culture and utilization in Malaysia: status, challenges and economic potential. Paper presented at the Seminar on Developing the Seaweed Aquaculture Sector in Malaysia. MIMA Bull 16:32-36

Kim JK, Yarish C, Hwang EK, Park M, Kim Y (2017) Seaweed aquaculture: cultivation technologies, challenges, and its ecosystem service. Algae 32:1-13

Kopprio GA, Cuong LH, Luyen ND, Duc TM, Ha TH, Huong LM, Gardes A (2021) Carrageenophyte-attached and planktonic bacterial communities in two distinct bays of Vietnam: eutrophication indicators and insights on ice-ice disease. Ecol Indic 121:107067

Kumar YN, Poong SW, Gachon C, Brodie J, Sade A, Lim PE (2020) Impact of elevated temperature on the physiological and biochemical responses of Kappaphycus alvarezii (Rhodophyta). PLoS One 15:e0239097

Lachnit T, Blümel M, Imhoff JF, Wahl M (2009) Specific epibacterial communities on macroalgae: phylogeny matters more than habitat. Aquat Biol 5:181-186

Largo DB, Fukami K, Nishijima T (1995) Occasional pathogenic bacteria promoting ice-ice disease in the carrageenan-producing red algae Kappaphycus alvarezii and Eucheuma denticulatum (Solieriaceae, Gigartinales, Rhodophyta). J Appl Phycol 7:545-554

Largo DB, Msuya FE, Menezes A (2020) Understanding disease and control in seaweed farming in Zanzibar. FAO Fisheries and Aquaculture Technical Paper No 662. FAO, Rome

Leonardi PI, Miravalles AB, Faugeron S, Flores V, Beltrán J, Correa JA (2006) Diversity, phenomenology and epidemiology of epiphytism in farmed Gracilaria chilensis (Rhodophyta) in Northern Chile. Eur J Phycol 41:247-257

Lim PE, Tan J, Phang SM, Nikmatullah A, Hong DD, Sunarpi H, Hurtado AQ (2013) Genetic diversity of Kappaphycus Doty and Eucheuma J. Agardh (Solieriaceae, Rhodophyta) in Southeast Asia. J Appl Phycol 26:1253-1272

Loureiro RR, Hurtado AQ, Chritchley AT (2017) Impact of AMPEP on epiphytes and diseases in Kappaphycus and Eucheuma cultivation. In: Hurtado AQ, Critchley AT, Neish IC (eds) Tropical seaweed farming trends, problems and opportunities: focus on Kappaphycus and Eucheuma. Springer, Cham, pp 111-120

Luhan MRJ, Avañcena SS, Mateo JP (2015) Effect of short-term immersion of Kappaphycus alvarezii (Doty) Doty in high nitrogen on the growth, nitrogen assimilation, carrageenan quality, and occurrence of "ice-ice" disease. J Appl Phycol 27:917-922

Mancuso FP, D’Hondt S, Willems A, Airoldi L, De Clerck O (2016) Diversity and temporal dynamics of the epiphytic bacterial communities associated with the canopy-forming seaweed Cystoseira compressa (Esper) Gerloff and Nizamuddin. Front Microbiol $7: 476$ 
Mariño M, Breckwoldt A, Teichberg M, Kasec A, Reuter H (2019) Livelihood aspects of seaweed farming in Rote Island, Indonesia. Mar Policy 107:103600

Mateo JP, Campbell I, Cottier-Cook EJ, Luhan MRJ, Ferriols VMEN, Hurtado AQ (2020) Analysis of biosecurity-related policies governing the seaweed industry in the Philippines. J Appl Phycol 32:2009-2022

Mendoza WG, Montaño NE, Ganzon-Fortes ET, Villanueva RD (2002) Chemical and gelling profile of ice-ice infected carrageenan from Kappaphycus striatum (Schmitz) Doty "sacol" strain (Solieriaceae, Gigartinales, Rhodophyta). J Appl Phycol 14:409-418

Mohan CV, Phillips MJ, Bhat BV, Umesh NR, Padiyar PA (2008) Farm-level plans and husbandry measures for aquatic animal disease and emergencies. Rev Sci Tech Off Int Epiz 27:161-173

Nor AM, Gray TS, Caldwell GS, Stead SM (2017) Is a cooperative approach to seaweed farming effectual? An analysis of seaweed cluster project (SCP) Malaysia. J Appl Phycol 29:2323-2337

Nor AM, Gray TS, Caldwell GS, Stead SM (2020) A value chain analysis of Malaysia's seaweed industry. J Appl Phycol 32:2161-2171

Pang T, Liu J, Liu Q, Li H, Li J (2015) Observations on pests and diseases affecting a eucheumatoid farm in China. J Appl Phycol 27:1975-1984

Periyasamy C, Rao PVS, Anantharaman P (2016) Spatial and temporal variation in carrageenan yield and gel strength of cultivated Kappaphycus alvarezii (Doty) Doty in relation to environmental parameters in Palk Bay Waters, Tamil Nadu, Southeast coast of India. J Appl Phycol 28:525-532

Potin P (2012) Intimate associations between epiphytes, endophytes, and parasites of seaweeds. In: Bischof K, Wiencke C (eds) Seaweed biology: novel insights into ecophysiology, ecology and utilization. Springer, New York, pp 203-234

Rodgers CJ, Carnegie RB, Chavez-Sanchez MC, Martinez-Chavez CC, Furones Nozal MD, Hine PM (2015) Legislative and regulatory aspect of molluscan health management. J Invertebr Pathol 131:242-255

Roleda MY, Hurd CL (2019) Seaweed nutrient physiology: application of concepts to aquaculture and bioremediation. Phycologia 58:552-562

Rusekwa SB, Campbell I, Msuya FE, Buriyo AS, Cottier-Cook EJ (2020) Biosecurity policy and legislation of the seaweed aquaculture industry in Tanzania. J Appl Phycol 32:4411-4422

Sade A, Ali I, Ariff MRM (2006) The seaweed industry in Sabah, East Malaysia. Jati 2:97-107

Sahu SK, Ingle KN, Mantri VA (2020) Epiphytism in seaweed farming: causes, status, and implications. In: Gothandam K, Ranjan S, Dasgupta N, Lichtfouse E (eds) Environmental Biotechnology Vol. 1. Environmental Chemistry for a Sustainable World, vol 44. Springer, Cham, pp 227-242

Scarfe AD, Palić D (2020) Aquaculture biosecurity: practical approach to prevent, control, and eradicate diseases. Aqua Health Manag:75-116
Subasinghe RP, Delamare-Deboutteville J, Mohan CV, Phillips MJ (2019) Vulnerabilities in aquatic animal production. Rev Sci Tech Off Int Epiz 38:423-436

Sulu R, Kumar L, Hay C, Pickering T (2004) Kappaphycus seaweed in the Pacific: review of introductions and field testing proposed quarantine protocols. Secretariat of the Pacific Community, Noumea pp 1-84

Tsiresy G, Preux J, Lavitra T, Dubois P, Lepoint G, Eeckhaut I (2016) Phenology of farmed seaweed Kappaphycus alvarezii infestation by the parasitic epiphyte Polysiphonia sp. in Madagascar. J Appl Phycol 28:2903-2914

Vairappan CS (2006) Seasonal occurrence of epiphytic algae on the commerciallly cultivated red alga Kappaphycus alvarezii (Solieriaceae, Gigartinales, Rhodophyta). J Appl Phycol 18:611-617

Vairappan CS, Chung CS, Hurtado AQ, Soya FE, Lhonneur GB, Critchley A (2008) Distribution and symptoms of epiphyte infection in major carrageenophyte-producing farms. J Appl Phycol 20:477-483

Vairappan CS, Anangdan SP, Tan KL, Matsunaga S (2010) Role of secondary metabolites as defense chemicals against ice-ice disease bacteria in biofouler at carrageenophyte farms. J Appl Phycol 22:305-311

Vairappan CS, Chung CS, Matsunaga S (2014) Effect of epiphyte infection on physical and chemical properties of carrageenan produced by Kappaphycus alvarezii Doty (Soliericeae, Gigartinales, Rhodophyta). J Appl Phycol 26:923-931

Valderrama D, Cai J, Hishamunda N, Ridler N, Neish IC, Hurtado AQ, Msuya FE, Krishnan M, Narayanakumar R, Kronen M, Robledo D, GascaLeyva E, Fraga J (2015) The economics of Kappaphycus seaweed cultivation in developing countries: a comparative analysis of farming systems. Aquac Econ Manag 19:251-277

Wahl M, Goecke F, Labes A, Dobretsov S, Weinberger F (2012) The second skin: ecological role of epibiotic biofilms on marine organisms. Front Microbiol 3:292

Walls AM, Edwards MD, Firth LB, Johnson MP (2017) Successional changes of epibiont fouling communities of the cultivated kelp Alaria esculenta: predictability and influences. Aqua Environ Interact 9:57-71

Ward GM, Faisan-Jr JP, Cottier-Cook EJ, Gachon C, Hurtado AQ, Lim PE, Matoju I, Msuya FE, Bass D, Brodie J (2020) A review of reported seaweed diseases and pests in aquaculture in Asia. $\mathrm{J}$ World Aquacult Soc 51:815-828

WWF (2014) Better management practices: budidaya rumput laut kotoni (Kappaphycus), sacol (K. striatum) and spinosum (Eucheuma denticulatum). WWF Indonesia, 48 pp

Yong WTL, Chin JYY, Thien VY, Yasir S (2014) Evaluation of growth rate and semi-refined carrageenan properties of tissue-cultured Kappaphycus alvarezii (Rhodophyta, Gigartinales). Phycol Res 62:316-321

Publisher's note Springer Nature remains neutral with regard to jurisdictional claims in published maps and institutional affiliations. 